\title{
Provenance discrimination of the last glacial sediments from the northeastern South China Sea and its paleoenvironmental indications
}

\author{
Fang Liu ${ }^{1,3}$, Chupeng Yang ${ }^{2}$, Xiaohong Chang ${ }^{2}$, and Zewen Liao ${ }^{1, *}$ \\ ${ }^{1}$ State Key Laboratory of Organic Geochemistry, Guangzhou Institute of Geochemistry, Chinese Academy of Sciences, \\ Guangzhou, China \\ ${ }^{2}$ Key Laboratory of Marine Mineral Resources of Ministry of Land and Resources, Guangzhou Marine Geological Survey, \\ Guangzhou, China \\ ${ }^{3}$ University of Chinese Academy of Sciences, Beijing, China
}

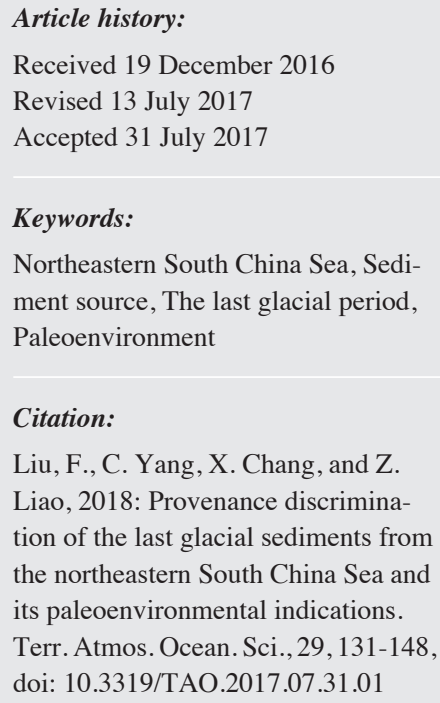

Keywords:

Northeastern South China Sea, Sediment source, The last glacial period, Paleoenvironment

Citation:

Liu, F., C. Yang, X. Chang, and Z. Liao, 2018: Provenance discrimination of the last glacial sediments from the northeastern South China Sea and its paleoenvironmental indications Terr. Atmos. Ocean. Sci., 29, 131-148, doi: 10.3319/TAO.2017.07.31.01

\begin{abstract}
A total of 849 core samples collected from two drilling core STD235 and ZSQD289 in the northeastern South China Sea were analyzed for elemental composition including total organic carbon (TOC), total nitrogen (TN), stable carbon and nitrogen isotopic composition $\left(\delta^{13} \mathrm{C}, \delta^{15} \mathrm{~N}\right)$, and clay mineral composition. Based on clay mineral assemblages and organic geochemistry characteristics, it is supposed that the terrestrial source for sediments at STD235 and ZSQD289 is mainly from southwestern Taiwan. Moreover, the sedimentary organic matter of site ZSQD289 was probably directly inputted from southwestern Taiwan submarine canyon, while the sedimentary organic matter of core STD235 was probably transported by deep water current. The chronology suggested that it covered the record since $\sim 19.7$ and $34.6 \mathrm{ka} \mathrm{BP}$ in site STD235 and ZSQD289 respectively. Before the Last Glacial Maximum (LGM), high TOC/TN ratios with low $\delta^{13} \mathrm{C}$ and $\delta^{15} \mathrm{~N}$ values might indicate that terrestrial organic input and nitrogen fixation was enhanced. During the LGM, gradually increased TOC, TN,$\delta^{13} \mathrm{C}$, and $\delta^{15} \mathrm{~N}$ values might result from the enhanced burial of organic carbon and higher marine primary production constrained by the strong winter monsoon. TOC/TN ratios and $\delta^{13} \mathrm{C}$ values generally present a decreased trend from LGM to Holocene (18 - $11 \mathrm{cal} \mathrm{ka} \mathrm{BP})$, strongly correlated to the terrestrial organic input and marine primary production reduced during this period. Since Holocene, the terrestrial organic input to both sites further reduced and maintained a low level, in according with a high sea level and a gradual intensified summer monsoon.
\end{abstract}

\section{INTRODUCTION}

South China Sea (SCS), located between the Asia landmass and the West Pacific, is one of the largest marginal seas in the world (Wang and Wang 1990). As a part of SCS, the northeastern SCS is surrounded by southern mainland China, Taiwan Island and Luzon arc and connected to the East China Sea and Pacific Ocean by the Taiwan Strait and Luzon strait in the east (Fig. 1). Numerous rivers including both the world's largest rivers (e.g., Mekong River, Pearl River, and Red River) and small mountainous rivers (e.g., rivers in southwestern Taiwan) supply as much as $570 \mathrm{Mt} \mathrm{yr}^{-1}$ of terrigenous sediments to SCS (Milliman and Syvitski 1992;

\footnotetext{
* Corresponding author

E-mail:liaozw@gig.ac.cn
}

Dadson et al. 2004). However, the northeastern SCS alone receives on less than $260 \mathrm{Mt} \mathrm{yr}^{-1}$ of river sediments mainly from three prominent sources, i.e., Pearl River, southwestern Taiwan, and Luzon arc system (Liu et al. 2010), occupying almost half of total terrigenous discharge to the entire SCS. Because of its location and continuous high sedimentation rates, the northeastern SCS provides an ideal area for highresolution studies of paleoenvironmental and paleoceanographic change (Bühring et al. 2004; Wang and Li 2009).

The East Asian Monsoon plays an important role in the climate fluctuation of the SCS. It results in differential land-sea heating between the Western Pacific Warm Pool and the Asian continent, and is characterized by seasonal switch in wind direction, precipitation and runoff (Wang et 
al. 2003). At the same time, a seasonal wind direction generates a reversal of the SCS surface currents, passing from a cyclonic gyre during the winter monsoon to an anticyclone during the summer monsoon, with strong influence from the Kuroshio intrusion (Fig. 1) (Wang and Wang 1990; Shaw and Chao 1994). In addition, the SCS deep water current, probably originating from a branch of the southward North Pacific Deep Water in the western Pacific, may cross the Luzon Strait and carry eastern and southern Taiwan-sourced resuspended fine grained sediments into the northeastern SCS (Fig. 1) (Lüdmann et al. 2005). Therefore, the sediment provenances of northeastern SCS are complicated because of the interaction of surface current with East Asian monsoon winds, the intrusion of the subsurface Kuroshio and deep water current (Shaw and Chao 1994; Su 2004). Most of previous studies mainly at SONNE Cruise 95 cores and Ocean Drilling Program (ODP) Leg 184 sites in the northeastern SCS considered the Pearl River as the main sedimentary source (Wang et al. 1999; Wehausen and Brumsack 2002; Boulay et al. 2003; Tamburini et al. 2003), but recent studies more emphasis a significant contribution derived from the northeast sources, i.e., Taiwan and/or the Yangtze River (Shao et al. 2007; Wan et al. 2007, 2010; Liu et al. 2008). Including the above studies, most of investigations on sediment provenance are mainly based on clay mineralogy and elemental geochemistry, however, discriminating the provenance of sedimentary organic matter on deep sea has seldom performed. Only some relevant studies focused on Pearl River and Taiwan Rivers estuaries and shelf of SCS
(Yu et al. 2010; Yang et al. 2011a; Hung et al. 2012; Zhang et al. 2014), little data are available to determine the sources and compositions of sedimentary organic matter from the slope and deep basin in the northeast of SCS. Furthermore, most of the paleoclimatic studies in the north of SCS concentrated on the reconstruction of long-term climatic variation until now (An et al. 1990; Zhao et al. 2001; Jia et al. 2003; Jian et al. 2003; Huang et al. 2005; Wei et al. 2006; Wan et al. 2007, 2008, 2010; Clift et al. 2014). Those reconstructions have shown that glacial stages were marked by a stronger winter monsoon with an increase of aridity over northern Asia, and interglacial periods were characterized by a stronger summer monsoon coupled with strengthened southwestern winds and enhanced monsoon rainfall over the continent (An et al. 1990; Wang and Wang 1990; Morley and Heusser 1997; Wang et al. 1999). In comparison, study on the climatic reconstruction of short-term and highresolution is relatively weak, and the work on centennialmillennial climatic and environmental variation in northern SCS needs strengthening. It has been reported that considerable climate variability and complex driving mechanism of regional climate change exist in northern SCS since the last glacial (Morley and Heusser 1997; Lin et al. 2006; He et al. 2008; Dai et al. 2015). Seeking insight into the relationship between climate and organic matter component in marine sediment since the last glacial period may provide new evidence for response to climate changes, which in turn may improve predictions of the future climate changes.

The bulk geochemical properties of organic matter,

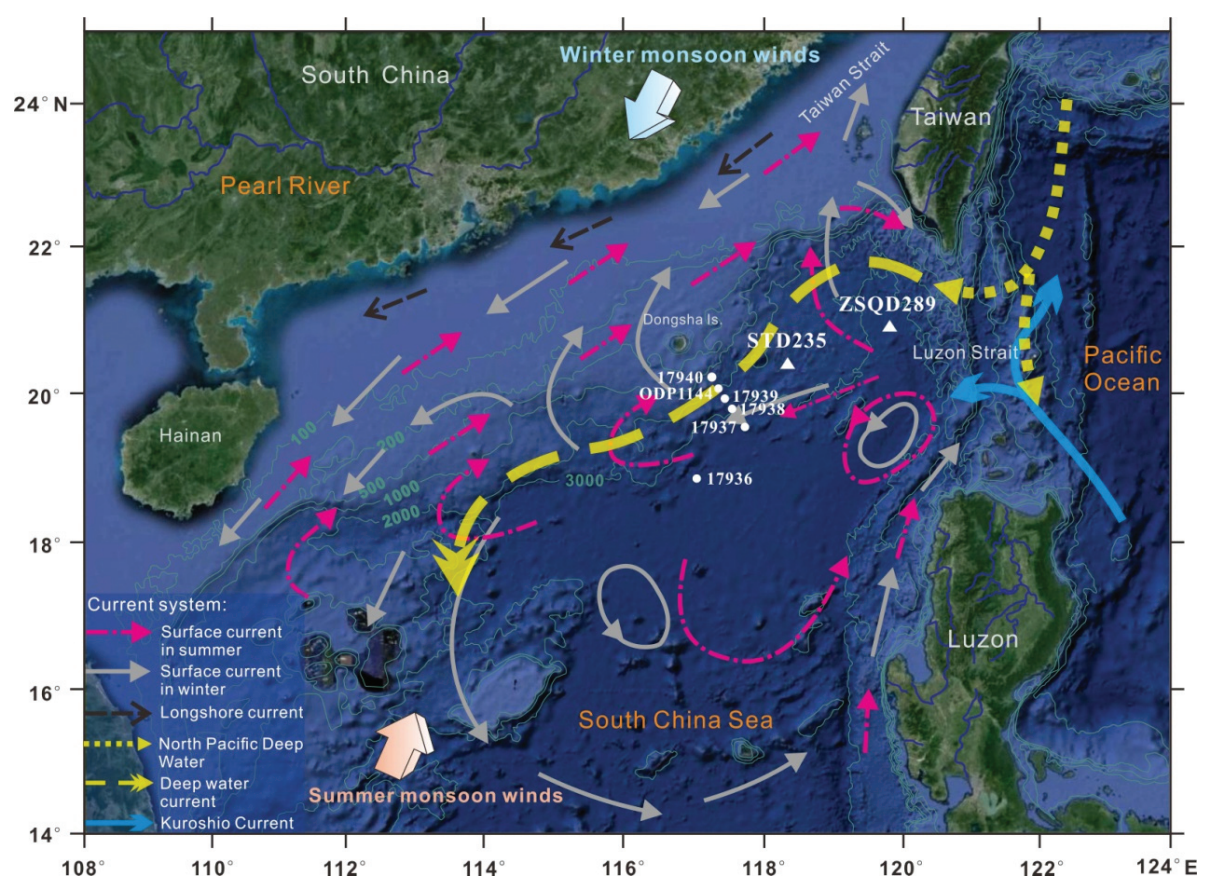

Fig. 1. Map of the northern SCS and locations of drilling samples discussed in this work. The location of ODP1144 from Wan et al. (2010), and the location of 17940, 17939, 17938, 17937, 17936 from Wang and Li (2009); Monsoon winds and current systems from Liu et al. (2010) and Lüdmann et al. (2005), and the background map from Google Earth, May 2016. 
including total organic carbon (TOC) content, total nitrogen $(\mathrm{TN})$, carbon to nitrogen $(\mathrm{TOC} / \mathrm{TN})$ ratios, and carbon $\left(\delta^{13} \mathrm{C}\right)$ and nitrogen $\left(\delta^{15} \mathrm{~N}\right)$ isotopes, are widely used to constrain the origins of sedimentary organic matter and reconstruct paleoclimate/paleoenvironment (Meyers 2003; Hu et al. 2006; Lamb et al. 2006; Yang et al. 2008; Castro et al. 2010; Volvoikar et al. 2014). Carbon and nitrogen isotope fractionation of terrestrial plants is more significant than algae because of distinct carbon assimilation pathways, resulting in terrestrial plants usually characterized by lighter carbon and nitrogen isotope ratio. At the same time, $\delta^{13} \mathrm{C}$ composition helps to distinguish between $\mathrm{C}_{3}\left(\delta^{13} \mathrm{C}=-37 \sim-20 \%\right)$ and $\mathrm{C}_{4}\left(\delta^{13} \mathrm{C}=-14 \sim-9 \%\right.$ ) photosynthetic plants (Deines 1980; O'Leary 1988). These values show some overlapping with $\delta^{13} \mathrm{C}$ from marine organic matters, which range from -22.0 to $-20 \%$ (Meyers 1994; Martinelli et al. 1999). For this reason, $\delta^{13} \mathrm{C}$ was applied to paleoenvironmental studies routinely combined with $\delta^{15} \mathrm{~N}$ and TOC/TN (Meyers 1994, 1997; Wilson et al. 2005). The present work is focused on organic geochemical signatures including TOC, TN and TOC/TN ${ }_{\text {weight }}$ ratios, and carbon $\left(\delta^{13} \mathrm{C}\right)$ and nitrogen $\left(\delta^{15} \mathrm{~N}\right)$ isotopes, combined with clay mineral compositions from lower slope and deep basin sediments in northeastern SCS, in order to provide clues for provenance of sediments and short-term paleoclimate and paleoenvironment changes on the northeastern SCS.

\section{METHODOLOGY}

\subsection{Samples}

Core STD235 $\left(20^{\circ} 21.15^{\prime} \mathrm{N}, 118^{\circ} 22.56^{\prime} \mathrm{E}\right)$ was taken from the continental slope of northeastern SCS, located in the northeast of ODP1144 $\left(20^{\circ} 3.18^{\prime} \mathrm{N}, 117^{\circ} 25.14^{\prime} \mathrm{E}\right)$ (Fig. 1), at a water depth of $2630 \mathrm{~m}$. The total length of the core was $8.55 \mathrm{~m}$. The lithology of core STD235 is characterized mainly by grey silty sand with thin grey layers of mud and sandy silt with moderate bioturbation. It can potentially reflect the marine environment by its stable sedimentary record without obvious disturbance.

Core ZSQD289 $\left(20^{\circ} 52.03^{\prime} \mathrm{N}, 119^{\circ} 52.31^{\prime} \mathrm{E}\right)$, was collected from the deep-sea basin of the northeastern SCS adjacent to the southwest of Taiwan (Fig. 1), at a water depth of $3605 \mathrm{~m}$. The total length of the core was $8.47 \mathrm{~m}$. The lithology is dominated by silica clay and calcareous in gray or dark gray, with thin layers of silica clay, calcareous clay and sandy silt with moderate bioturbation.

\subsection{Methods}

A total of 849 core samples (428 from STD235 and 421 from ZSQD289) collected at interval of $2 \mathrm{~cm}$ were prepared for analysis. All samples were freeze-dried and ground into fine powder for analysis of total organic carbon (TOC), total nitrogen (TN) and their stable isotope ratios, $\delta^{13} \mathrm{C}$ and $\delta^{15} \mathrm{~N}$ at the State Key Laboratory of Organic Geochemistry at Guangzhou Institute of Geochemistry. In addition, 171 samples were selected (86 from STD235, 85 from ZSQD289) for analysis of clay mineral.

The chronology of the core STD235 was based on 6 AMS ${ }^{14} \mathrm{C}$ dates of planktonic foraminifera (G.ruber), and the core ZSQD289 was based on $2 \mathrm{AMS}^{14} \mathrm{C}$ dates of planktonic foraminifera (G.ruber) and 2 AMS ${ }^{14} \mathrm{C}$ dates of bulk organic matter (Table 1). Samples were pretreated at Guangzhou Institute of Geochemistry, and then the dating of material was carried out at the State Key Laboratory of Nuclear Physics and Technology (Peking University, China). The radiocarbon ages of planktonic foraminifera and bulk organic matter have been calibrated using the CALIB 6.0 program based on the Marine09 and IntCal09 calibration curves, respectively (Stuiver and Reimer 1993; Reimer et al. 2009) (Table 1). The age of each depth was interpolated from the two nearest dates.

Table 1. AMS ${ }^{14} \mathrm{C}$ ages dated on core STD235 and ZSQD289.

\begin{tabular}{|c|c|c|c|c|c|}
\hline Sample core & Depth (cm) & Material & $\mathrm{AMS}^{14} \mathrm{C}$ age (yr BP) & Calendar age (yr BP, 1б) & MIS $^{\mathbf{b}}$ \\
\hline STD235 & 55 & G.ruber ${ }^{\mathrm{a}}$ & $3760 \pm 25$ & $3685 \pm 50$ & 1 \\
\hline STD235 & 315 & G.ruber & $11910 \pm 30$ & $13352 \pm 47$ & 1 \\
\hline STD235 & 395 & G.ruber & $12935 \pm 40$ & $14774 \pm 215$ & 2 \\
\hline STD235 & 575 & G.ruber & $13750 \pm 60$ & $16508 \pm 222$ & 2 \\
\hline STD235 & 705 & G.ruber & $14300 \pm 60$ & $16955 \pm 99$ & 2 \\
\hline STD235 & 825 & G.ruber & $16310 \pm 70$ & $19148 \pm 114$ & 2 \\
\hline ZSQD289 & 60 & G.ruber & $2930 \pm 100$ & $3088 \pm 133$ & 1 \\
\hline ZSQD289 & 465 & G.ruber & $15420 \pm 160$ & $18765 \pm 112$ & 2 \\
\hline ZSQD289 & 652 & organic matter & $25360 \pm 80$ & $30297 \pm 126$ & 3 \\
\hline ZSQD289 & 808 & organic matter & $29140 \pm 100$ & $33750 \pm 338$ & 3 \\
\hline
\end{tabular}

Note: a: G. ruber (Globigerinoides ruber) is a kind of Planktonic foraminifera species. b: MIS is marine isotope stage. 


\subsubsection{Elemental Composition}

Total organic carbon (TOC) and nitrogen (TN) were analyzed with a Vario EL III Elemental analyzer. Prior to analysis, freeze-dried samples (10 - $20 \mathrm{mg}$ ) were acidified $(4 \mathrm{~N} \mathrm{HCl})$ to remove carbonates and dried. 849 samples were all analyzed in duplicate, with the mean deviation of the duplicate measurements for $\mathrm{C}$ and $\mathrm{N}<0.05 \%$. In order to control the instrument analysis quality, one sample was measured repeatedly at different time, and the resulted mean deviations $(\sigma)$ of multiple analyses $(\mathrm{n}=5)$ for $\mathrm{C}$ and $\mathrm{N}$ were 0.02 and $0.003 \%$, respectively.

\subsubsection{Stable Isotope Analysis}

The stable carbon and nitrogen isotope compositions of carbonate-free samples were measured using a Finnigan Delta Plus XL (Instrument ID: CE Flash EA 1112). All isotope values were presented in standard $\delta$-notation in per mil $(\%)$ with respect to Vienna-Pee Dee Belemnite (VPDB) carbon and atmospheric nitrogen $\left(\mathrm{N}_{2}\right)$. The mean deviation of $\delta^{13} \mathrm{C}$ and $\delta^{15} \mathrm{~N}$ based on replicate analyses were $<0.25 \%$ and $<0.3 \%$, respectively.

\subsubsection{Clay Mineral Analysis}

Clay mineral $(<2 \mathrm{~mm})$ were separated based on Stoke's settling velocity principle after removing carbonate and organic matter by treatment with $15 \%$ hydrogen peroxide and $25 \%$ acetic acid, respectively. Clay mineralogy determinations were made by X-ray diffraction on X'Pert with $\mathrm{CuK} \alpha$ radiation $(40 \mathrm{kV}, 200 \mathrm{~mA})$. Identification of clay minerals was made mainly according to the position of the (001) series of basal reflections on the XRD diagrams. Semiquantitative estimates of peak areas of the basal reflections for the main clay mineral groups of smectites (smectite+illite mixed layers) (17 ̊), illite (10 ̊), and kaolinite/chlorite (7 $\AA$ ) were carried out using the MDI Jade 5.0 software. Relative proportions of kaolinite and chlorite were determined based on the ratios of the 3.57/3.54 $\AA$ peak areas. The empirical factors introduced by Biscaye (1965) were not used when generating relative weight percentages of each clay mineral. Relative clay mineral abundances were given in percent (Table 2).

\section{RESULTS}

\subsection{Chronology}

Six AMS ${ }^{14} \mathrm{C}$ dates range from $\sim 1.76$ to $\sim 19.70 \mathrm{cal} \mathrm{ka}$ $\mathrm{BP}$ on core STD235 and four AMS ${ }^{14} \mathrm{C}$ dates range from $\sim 0.84$ to $\sim 34.59 \mathrm{cal} \mathrm{ka} \mathrm{BP}$ on core ZSQD289 were obtained respectively, indicating these record covered the pre-LGM, LGM, deglaciation, and the Holocene (Table 1 and Fig. 2). Accordingly, the average sedimentation rate for different segments was calculated. In the core STD235, low values occur in Holocene $\left(26.9 \mathrm{~cm} \mathrm{ka}^{-1}\right)$, and high values occur in the early and late deglaciation $\left(54.7-56.3 \mathrm{~cm} \mathrm{ka}^{-1}\right)$ and remarkably high values occur in the middle deglaciation (up to $290.8 \mathrm{~cm} \mathrm{ka}^{-1}$ ). In the core ZSQD289, low values occur in LGM, deglaciation and Holocene (16.2 - $\left.25.8 \mathrm{~cm} \mathrm{ka}^{-1}\right)$, and high value occur in pre-LGM ( 45.2 $\left.\mathrm{cm} \mathrm{ka}^{-1}\right)$ (Fig. 2). In both cores, sedimentation rates are higher in glacial period (80.7 $\mathrm{cm} \mathrm{ka}^{-1}$ for STD235, $26.1 \mathrm{~cm} \mathrm{ka}^{-1}$ for ZSQD289) than interglacial period $\left(27.0 \mathrm{~cm} \mathrm{ka}^{-1}\right.$ for STD235, $25.8 \mathrm{~cm} \mathrm{ka}^{-1}$ for ZSQD289).

\subsection{Clay Mineral Composition}

The percentage of illite, smectite, chlorite and kaolinite in the clay mineral assemblages of 86 samples from STD235 range from $34-54 \%(42 \pm 4.2 \%), 14-41 \%$ (31 $\pm 5.8 \%), 13-21 \%(17 \pm 1.8 \%)$, and $9-13 \%(10 \pm 1.0 \%)$, respectively (Table 2). There is preponderance of illite over other minerals. The percentage of illite, smectite, chlorite and kaolinite in the clay mineral assemblages of 85 samples from ZSQD289 range from $33-60 \%$ (44 $\pm 5.8 \%), 14-40 \%$ $(29 \pm 5.7 \%), 15-21 \%(18 \pm 1.4 \%)$, and $8-11 \%(9 \pm 0.7 \%)$, respectively. The clay mineral components of 85 samples from ZSQD289 are generally similar to those of STD235, with preponderance of illite over other minerals (Table 2). In general, the clay mineral components of STD235 and ZSQD289 show no significant changes between glacial and interglacial periods (Fig. 3).

\subsection{TOC, TN, and the C/N Ratios}

TOC values in cores STD235 and ZSQD289 range from $0.55-2.17 \%$ (average $1.10 \pm 0.27 \%$ ) and $0.49-1.24 \%$ (average $0.82 \pm 0.15 \%$ ), respectively. The ZSQD289 core had an average TOC value of 0.89 and $0.68 \%$ during glacial and interglacial period respectively, whereas the STD235 core had a higher average of 1.30 and $0.84 \%$ during glacial and interglacial period respectively. TN values in the STD235 and ZSQD289 sediments have a mean value of 0.13 $\pm 0.02 \%(0.08-0.17 \%)$ and $0.10 \pm 0.02 \%(0.04-0.15 \%)$ respectively, which co-varied with their corresponding TOC values $\left(\mathrm{R}^{2}=0.57\right.$ and 0.68 , respectively). The TOC/ TN weight ratios of the STD235 and ZSQD289 cores range from 5.4 - 16.1 (average $8.3 \pm 1.49$ ) and 5.7 - 14.8 (average $8.1 \pm 0.93$ ), respectively (Fig. 3).

Overall decreasing trend of TOC and TOC/TN values is observed from bottom to top in the core STD235 sediments, with five abrupt rises of TOC/TN values corresponding to their higher TOC abundance (Fig. 3). Comparatively, the core ZSQD289 shows higher concentration of TOC and $\mathrm{TN}$ in the middle and bottom, and lower in the upper part, with a slight upward decrease of TOC/TN values. However, it is similar in both cores that average values of TOC, TN, 
and TOC/TN in the glacial period are higher than interglacial period.

\subsection{Stable Carbon and Nitrogen Isotope Composition}

In core $S T D 235$, the $\delta^{13} \mathrm{C}$ values fluctuate within a range of -23.8 and $-21.0 \%$ (on average $-21.9 \pm 0.49 \%$ ). Rhythmic fluctuations of the isotope signal delineate an upward gradual decreasing trend in $\delta^{13} \mathrm{C}$ over $15 \mathrm{ka}$. The $\delta^{13} \mathrm{C}$ values fluctuate dramatically in deeper core STD235, and five obvious lower values respectively covary with higher TOC and TOC/TN values (Fig. 3a). $\delta^{15} \mathrm{~N}$ values fluctuate between 2.3 and $4.5 \%$ (on average $3.5 \pm 0.56 \%$ ), showing a strong fluctuation on the bottom and a decreased trend along upward core.

The $\delta^{13} \mathrm{C}$ values in core ZSQD289 range from -24.5 to $-20.4 \%$ (on average $-22.2 \pm 0.60 \%$ ). In glacial period, the $\delta^{13} \mathrm{C}$ values fluctuate in higher values compared to the interglacial period. The $\delta^{15} \mathrm{~N}$ values fluctuate between 2.1 and 5.8\%o (on average $4.7 \pm 0.68 \%$ ). The $\delta^{15} \mathrm{~N}$ values present a similar trend with $\delta^{13} \mathrm{C}$ values from 34.6 to $15 \mathrm{ka} \mathrm{BP}$, namely gradual decrease first and then increase (Fig. 3b). And after $15 \mathrm{ka}, \delta^{13} \mathrm{C}$ values show a decreased trend, while $\delta^{15} \mathrm{~N}$ values fluctuate at high level first and then decrease in the late Holocene.

\section{DISCUSSION}

\subsection{Sedimentation Rate and Its Control Factors}

The present study site STD235 and ZSQD289 both shows the higher sedimentation rate during glacial period than Holocene (Fig. 2). This is consistent with other sites in northern SCS where the glacial sedimentation rate is generally higher than interglacial time (Wang 1999). In general, the accumulation rates in SCS depend very much on the sediment discharge from rivers, and the sedimentation rate within a marginal sea is highest near the river mouths and decrease with distance from the coast (Lisitzin 1972). During the last glacial time, the continental margin extended to the present 100 - $120 \mathrm{~m}$ isobaths (Wang and Sun 1994), and the erosion of the newly exposed shelf and the direct discharge of terrigenous fluvial matter into the deep sea increased the terrigenous sediments supply to the research sites. This correlation between the supply of continental material and glacial low sea level periods in the SCS has been well documented (Wang and Li 2009).

However, the difference of sedimentation rates between the core STD235 and ZSQD289 indicates the relationship

Table 2. Average composition of clay minerals from Pearl River, Luzon, southwestern (SW) Taiwan, Yangtze River and STD235, ZSQD289 cores.

\begin{tabular}{cccccc}
\hline Source & Number of samples & Illite (\%) & Chlorite (\%) & Kaolite (\%) & Smectite (\%) \\
\hline Pearl River $^{\mathrm{a}}$ & 37 & 31 & 18 & 46 & 5 \\
Luzon $^{\mathrm{a}}$ & 35 & 1 & 7 & 5 & 87 \\
SW Taiwan $^{\mathrm{a}}$ & 19 & 55 & 43 & 1 & 1 \\
Yangtze River $^{\mathrm{b}}$ & - & 69 & 16 & 9 & 5 \\
STD235 & 86 & $42 \pm 4.2$ & $17 \pm 1.8$ & $10 \pm 1.0$ & $31 \pm 5.8$ \\
ZSQD289 & 85 & $44 \pm 5.8$ & $18 \pm 1.4$ & $9 \pm 0.7$ & $29 \pm 5.7$ \\
\hline
\end{tabular}

Note: a: Data from Liu et al. (2008, 2010). b: from Wan et al. (2010).
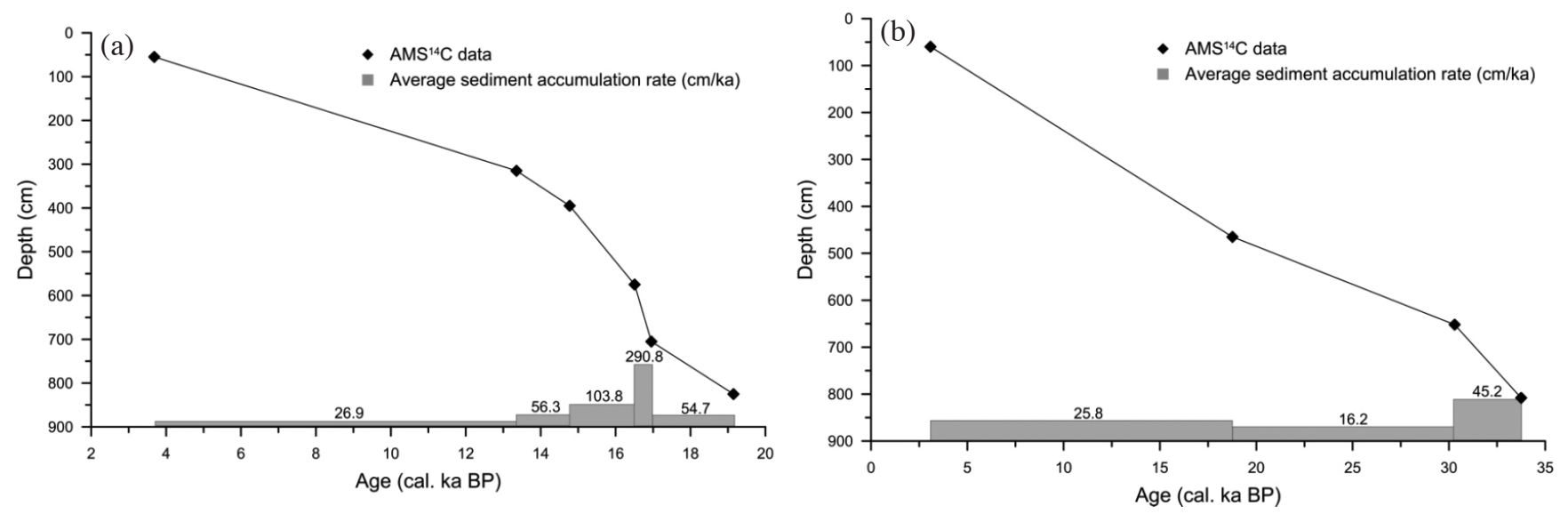

Fig. 2. Age-depth curves of (a) Core STD235 and (b) ZSQD289. Average sediment accumulation rates are marked. 

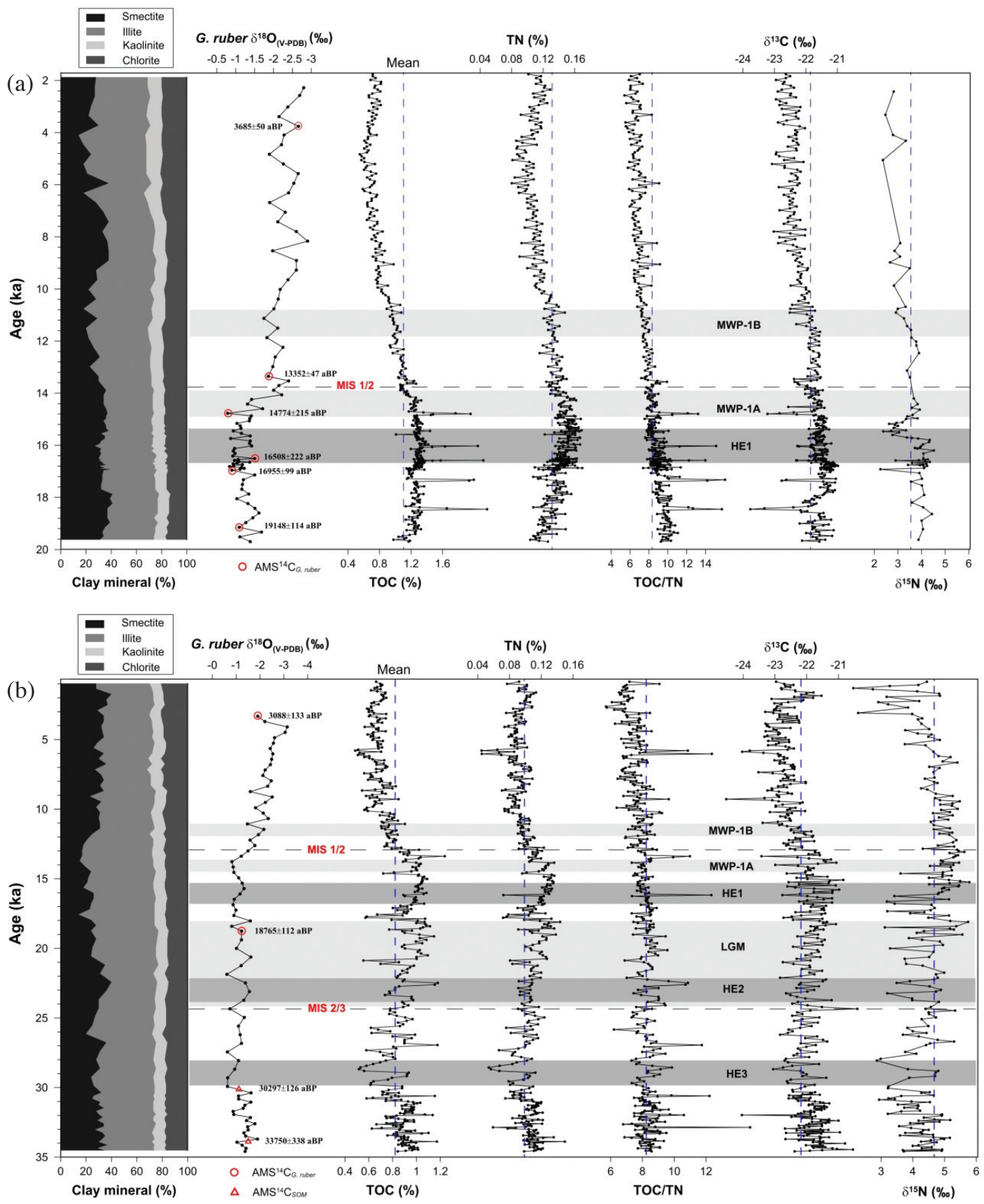

Fig. 3. The age framework, variation curves of clay mineral content, planktonic foraminifera $\delta^{18} \mathrm{O}$, TOC and TN concentrations, TOC/TN weight ratios and $\delta^{13} \mathrm{C}, \delta^{15} \mathrm{~N}$ values from (a) STD235 and (b) ZSQD289.

between river discharge and deep-sea deposition is not the sole cause of the high sedimentation rates (Fig. 2), due to various sediment transports and environmental changes. Accordingly, we collected and compared the sedimentary rate of surrounding cores from northern SCS (Table 3). The sedimentary rate in the last 12 ka years of the 17940 , located on the northwest part, is $70 \mathrm{~cm} \mathrm{ka}^{-1}$, and towards the southeast, core ODP1144 is $61 \mathrm{~cm} \mathrm{ka}^{-1}, 17939$ is $33.3 \mathrm{~cm} \mathrm{ka}^{-1}, 17938$ is $21.6 \mathrm{~cm} \mathrm{ka}^{-1}, 17937$ is $16.6 \mathrm{~cm} \mathrm{ka}^{-1}$, decreasing gradually from northwest to southeast. Meanwhile the core STD235 and ZSQD289, located in the northeast of ODP1144, were 27.0 and $25.8 \mathrm{~cm} \mathrm{ka}^{-1}$ respectively. Clearly, river discharge and monsoon-driven surface current transportation (e.g., Liu et al. 2003; Boulay et al. 2005; Wan et al.2007) is not needed to explain this trend to rapidly decreasing sedimentation rate into deeper water. Seismic profiles provide evidence that there has been strong deep water current transport and deposition in the northern SCS (Lüdmann et al. 2005; Shao et al. 2007). Channels formed by bottom currents occur in water depth of $1000-2700 \mathrm{~m}$, extending from the northeast to 
Table 3. Sedimentary rates of cores collected from the northeastern SCS ${ }^{\text {a }}$ (for location of cores see Fig. 1).

\begin{tabular}{|c|c|c|c|c|c|c|c|}
\hline Core & $17940^{\mathrm{a}}$ & ODP1144 & 17939 & 17938 & 17937 & STD235 & ZSQD289 \\
\hline Location & $\begin{array}{l}20^{\circ} 7.0^{\prime} \mathrm{N} \\
117^{\circ} 23^{\prime} \mathrm{E}\end{array}$ & $\begin{array}{c}20^{\circ} 3.18^{\prime} \mathrm{N} \\
117^{\circ} 25.14^{\prime} \mathrm{E}\end{array}$ & $\begin{array}{l}19^{\circ} 58.2^{\prime} \mathrm{N}, \\
117^{\circ} 27.3^{\prime} \mathrm{E}\end{array}$ & $\begin{array}{l}19^{\circ} 47.2^{\prime} \mathrm{N} \\
117^{\circ} 32.3^{\prime} \mathrm{E}\end{array}$ & $\begin{array}{c}19^{\circ} 30^{\prime} \mathrm{N} \\
117^{\circ} 39.9^{\prime} \mathrm{E}\end{array}$ & $\begin{array}{l}20^{\circ} 21.15^{\prime} \mathrm{N}, \\
118^{\circ} 22.56^{\prime}\end{array}$ & $\begin{array}{l}20^{\circ} 52.03^{\prime} \mathrm{N}, \\
119^{\circ} 52.31^{\prime} \mathrm{E}\end{array}$ \\
\hline Sed. thick (m) & 8 & 7.5 & 4 & 2.6 & 2 & 2.8 & 2.9 \\
\hline Age (ka) & 11.5 & 12.29 & $\sim 12$ & $\sim 12$ & $\sim 12$ & 12.0 & 12.0 \\
\hline Av. sed. rate $\left(\mathrm{cm} \mathrm{ka}^{-1}\right)$ & 70 & 61 & 33.3 & 21.6 & 16.6 & 27.0 & 25.8 \\
\hline Sed. thick (m) & 13.3 & 46 & 12.8 & 11.5 & 11 & 8.55 & 8.46 \\
\hline Age (ka) & $\sim 40$ & 40.1 & $\sim 40$ & $\sim 40$ & $\sim 40$ & 19.7 & 34.6 \\
\hline Av. sed. rate $\left(\mathrm{cm} \mathrm{ka}^{-1}\right)$ & 33.2 & 114.7 & 32 & 28.8 & 27.5 & 47.6 & 25.0 \\
\hline
\end{tabular}

Note: a: Data of 17940, 17939, 17938, 17937, and ODP 1144 from Shao et al. (2007).

southwest, and leading to the accumulation of discontinuous drifts with higher sedimentation rates on the eastern side of each channel (Fig. 1; Shao et al. 2007). Therefore, it is most likely that some NE-SW-trend transportation and deposition of deep water bottom current on the north continental slope of the SCS lead to the accumulation of some discontinuous drifts with higher sedimentation rates on the study sites (such as 17940 and ODP1144). The core STD235 was exactly located in water depth of $2630 \mathrm{~m}$ which was in the range of the flowing path of deep water current, and formed sedimentary drift with a high sedimentation rate in the last glacial period. In contrast, the core ZSQD289 may be less influenced by deep water current, thus showed lower sedimentary rate whether in the Holocene or in the glacial stage.

The sedimentary rate in the last 12 ka years of the 17940 is $70 \mathrm{~cm} \mathrm{ka}^{-1}$ decreasing gradually from northwest to southeast. But in the last 40 ka years, ODP1144 is highest reaching $114.7 \mathrm{~cm} \mathrm{ka}^{-1}$ and decreasing northwestward and southeastward (Table 3). And in the core STD235, the remarkably high values occur in the middle deglaciation (up to $\sim 290.8 \mathrm{~cm} \mathrm{ka}^{-1}$ ). The above results may reflect the movement of the deep water channel with time. Wan et al. (2010) considered that bottom current sedimentation in the northern SCS is strongly correlated to sea-level change. Their results including clay minerals, grain size and mass accumulation rate of terrigenous materials from ODP1144, all show strong glacial-interglacial cyclicity (Wan et al. 2010). A similar pattern of cyclic change of clay minerals was seen in sediments at ODP 1145 (Boulay et al. 2005) and ODP1146 (Liu et al. 2003). It is noteworthy that an opposing variation of East Asian summer monsoon intensity (Guo et al. 2000) and terrigenous flux and grain sizes at ODP Site 1144 (Wan et al. 2010) excludes the possibility that monsoon strength is the primary control on sediment delivery rates to the continental margin in this area. If monsoon is controlling erosion rates on onshore, the sediment must be stored onshore before being redeposited into the deep sea. Thus, we conclude that bottom current deposition is highly dependent on sea-level fluctuations. In general, we suggest that the high accumulation-rate sediments results from the combined actions of both deep-water current and terrigenous supply.

\subsection{Source Discriminations of Sediments}

\subsubsection{Implication from Clay Minerals}

Sediments derived from various source rocks have different clay mineral assemblages, so it can be used to determine the sediment provenance (Liu et al. 2003; Boulay et al. 2005; Lu et al. 2006; Wan et al. 2008). According to previous studies, terrigenous clastic sediments in northeastern SCS were derived mainly from the Pearl River in south China, rivers in SW Taiwan, and rivers in Luzon (Liu et al. 2010, 2013). Although eolian input from North Asia carried by the East Asian winter monsoon was also suggested as an important source for terrigenous sediments in northern SCS during some geological periods (Wang et al. 1999; Boulay et al. 2003; Tamburini et al. 2003), further investigation on clay mineralogy and the detrital mean grain size emphasized a significant contribution of river-borne terrigenous sediments to the northern SCS (Wan et al. 2007).

The data about clay mineral composition from relevant rivers has been collected (Table 2) and plotted in the ternary diagram of smectite-kaolinite-(illite+chlorite) (Fig. 4). Figure 4 is the ternary diagram and shows that the clay mineral assemblages of both drilling cores are close to those from the Taiwan source and largely overlap with eastern NE SCS. Wan et al. (2010) have shown high-resolution records of clay minerals, grain size and mass accumulation rate of terrigenous materials from ODP1144 and proved that the primary source for sediments at ODP1144 since 3 Ma was from Taiwan. Moreover, seismic data revealed that there are large submarine canyons off the southwestern Taiwan which could efficiently transported terrestrial sediments from the inland of southwestern Taiwan to the northeastern SCS (Chuang and Yu 2002). A recent clay mineral study also indicated that Taiwan-sourced sediments could be transported westward to the northern slope (Liu et al. 2011). Based on the analysis and our results above, it is assumed 


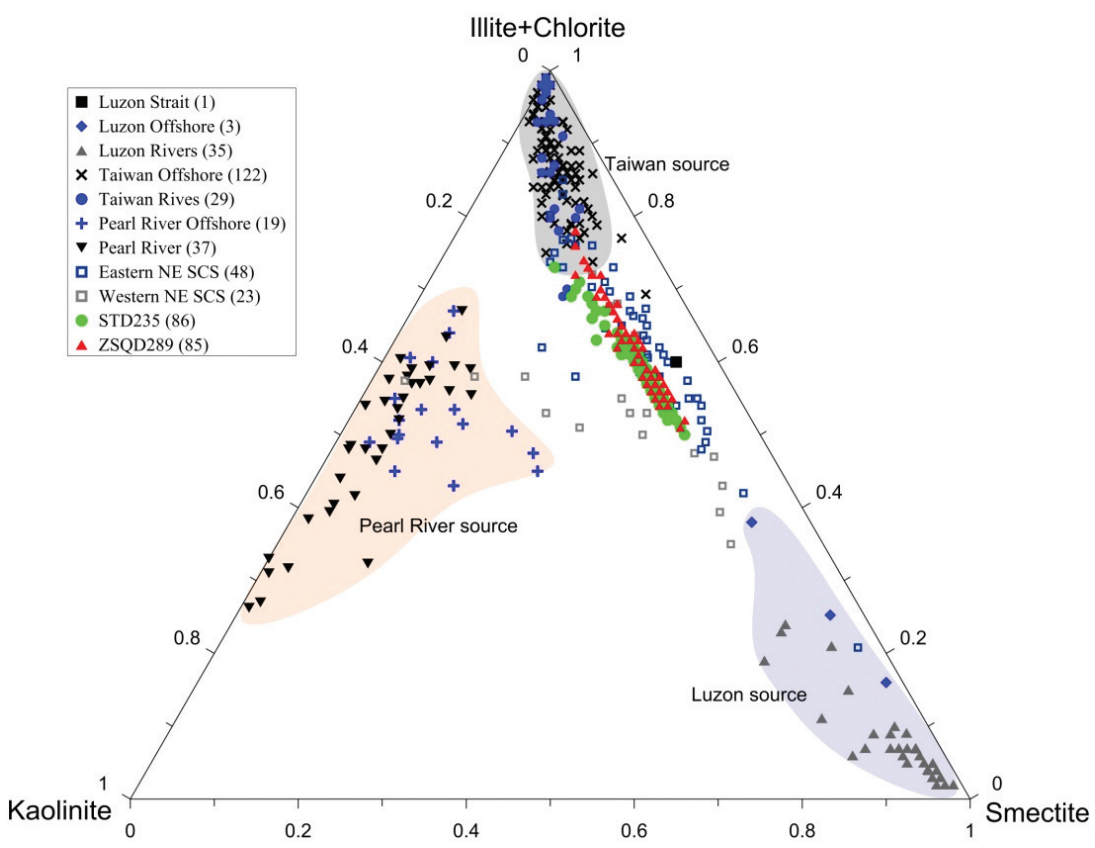

Fig. 4. Comparison of clay mineral assemblages among SW Taiwan, the Pearl River, Luzon, and the NE SCS. Data of SW Taiwan, the Pearl River, Luzon, and NE SCS from Liu et al. (2010). Inside the legend box, the numbers in the brackets represent the sample numbers used for the data compilations.

that the clay mineral of core STD235 and ZSQD289 might be largely derived from the sediment supply of SW Taiwan Rivers. However, our results did not exclude the contribution of sediment supply from Luzon arc to the study sites. Clay mineral results showed that the sediments in the core STD235 and ZSQD289 had higher content of smectite. According to previous research, high contents of smectite within the sediments of the northeastern SCS have been suggested to originate from Luzon arc (Liu et al. 2010). In addition, the bulk sediments may have other provenances because the sediment with different size in marine environments may have much variable sources and hydrodynamic sorting effects as well. Those indeterminate factors may affect on discriminating the sediment provenance. Thus, further research is needed to distinguish sources of sediment in northeastern SCS.

\subsubsection{Implication from Organic Geochemical Characteristics}

Despite evidence for substantial alteration during its sedimentation, organic matter retains considerable information about its source and its depositional environment. The organic matter from terrestrial provenance is generally characterized by TOC/TN ratios $>12, \delta^{13} \mathrm{C}$ values between $-26 \sim-27 \%$ and $\delta^{15} \mathrm{~N}$ values from -5 to - $1 \%$ o. In contrast, the organic matter from marine provenance is generally characterized by TOC/TN ratios of $4-10, \delta{ }^{13} \mathrm{C}$ values between -22 and $-20 \%$ and $\delta^{15} \mathrm{~N}$ values between 2 to $10 \%$ o (Meyers
1994; Martinelli et al. 1999). Thus, TOC/TN weight ratio, $\delta^{13} \mathrm{C}$ and $\delta^{15} \mathrm{~N}$ values of bulk sediment are generally utilized as valid source indicators of sedimentary organic matter (Meyers 1997; Burnett et al. 2011).

$\delta^{15} \mathrm{~N}$ values usually are not strong enough for identifying the source of organic matters because the source signature of $\delta^{15} \mathrm{~N}$ may be altered, associated with nitrogen isotope fraction in the geochemical process such as nitrogen fixation, denitrification and degradation of organic matter. While studying nitrogen isotopes from clay-rich environments, one major concern is the potential influence of inorganic nitrogen on the isotopic signature of the bulk sediment. To estimate this influence, data from both sites were plotted on a TN (wt \%) vs. TOC (wt \%) diagram, and the mean TN\% contribution of inorganic nitrogen to the bulk sediments is estimated as the value at y-intercept for a cross-plot of TOC and TN (Figs. 5a and b) (Nijenhuis and de Lange 2000; Arnaboldi and Meyers 2006). We perform statistical analysis and find TOC and TN is linear fitting for samples from ZSQD289 in both glacial and interglacial periods. That indicates the organic nitrogen in the site ZSQD289 basically has the same resource with organic carbon, little affected by inorganic nitrogen. However, the positive yaxis intercept for site STD235 samples during glacial period indicates that inorganic nitrogen may account for at least $11 \%$ of the total nitrogen pool of these sediments. Therefore inorganic nitrogen may have a great effect on the $\delta^{15} \mathrm{~N}$ values of STD235 core in glacial period. But there is a lack of correlation between $\delta^{15} \mathrm{~N}$ and $\mathrm{TN}$ for the whole record 

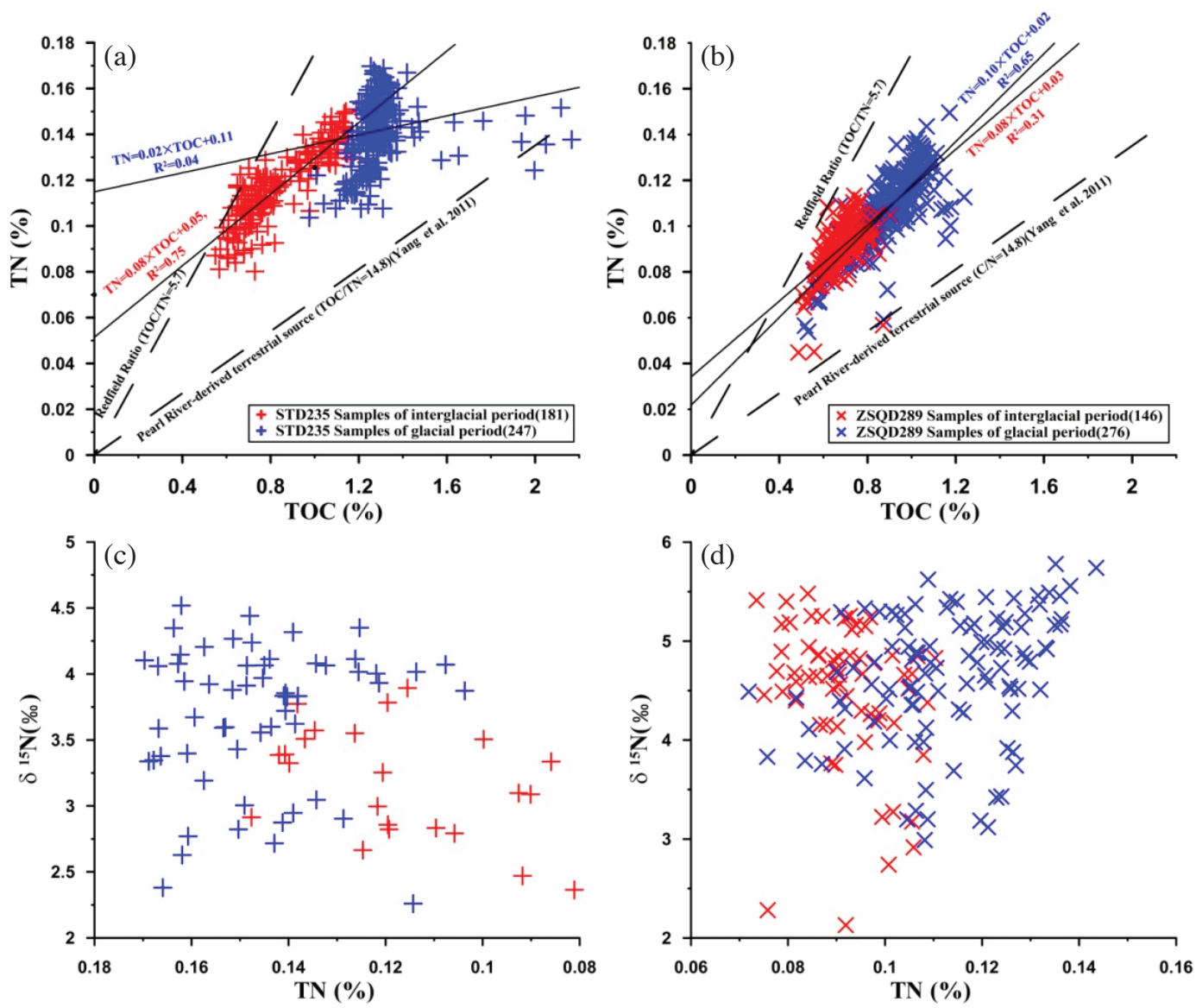

Fig. 5. Relationship between TOC $\%$ and TN\%, $\delta^{15} \mathrm{~N}$ and TN in the STD235 and ZSQD289 drilling sites during glacial and interglacial periods, compared with marine field defined by Redfield Ratio and terrestrial source. $(\mathrm{C} / \mathrm{N})_{\text {weight }}$ of Redfield Ratio is 5.7, $(\mathrm{C} / \mathrm{N})_{\text {weight }} \times 1.17=(\mathrm{C} / \mathrm{N})_{\text {atomic }}(\mathrm{Redfield}$ 1934). (C/N $)_{\text {weight }}$ of Pearl River-derived terrestrial source is from Yang et al. (2011a).

(Figs. 5c and d), suggesting this inorganic enrichment is not a determined factor for the changing $\delta^{15} \mathrm{~N}$ (Higginson et al. 2003). If the isotopic signature of site STD235 has been influenced by adsorption of inorganic nitrogen during glacial period, low $\delta^{15} \mathrm{~N}$ values should correspond to the low values of the TOC/TN ratios (Tamburini et al. 2003), which is not the case in Fig. 3a. In fact lower values of nitrogen isotopes during glacial period often coincide with higher TOC/TN ratios (Fig. 3a). This indicates that although inorganic nitrogen is present in sediments at site STD235 during glacial period, $\delta^{15} \mathrm{~N}$ values bear information on the nature of the organic material.

The majority of depositional organic matters undergo no further diagenetic changes after burial, and the TOC/TN ratio in sediments is indicative of the source of depositional organic matter (Meyers 1994, 1997; Hedges and Oades 1997; Louchouarn et al. 1999). The TOC/TN ratios of the sediments at sites STD235 and ZSQS289 are on average 8.3 and 8.1 respectively, falling into between the range of marine field defined by the Redfield Ratio and terrestrial field defined by Pearl River-derived source (Fig. 5). That suggests a mixture of terrestrial while with dominant marine sources. The TOC/TN ratios of sites STD235 and ZSQD289 during interglacial period fall more closely to Redfield Ratio (Redfield 1934), that indicates marine source may have dominant contribution to interglacial sediments whereas terrestrial supply increased in the glacial period, and the discrepancy between glacial and interglacial period at site STD235 is more remarkable. The discrepancy in the TOC/ TN ratios between the two sites may be correlated with the finding that sediments from site STD235 bear an important percentage of inorganic nitrogen during glacial period (see the above discussion). Modification of the carbon isotopic composition resulted from preferential decomposition of ${ }^{13} \mathrm{C}$-enriched organic matters during transport, deposition and diagenesis has been reported, but generally small as $<-2 \%$ o (Marthur et al. 1992). Thus, the $\delta^{13} \mathrm{C}$ values may better reflect the organic sources than $\delta^{15} \mathrm{~N}$ and TOC/TN ratios. The range of $\delta^{13} \mathrm{C}$ at site STD235 and ZSQD289 are $-23.8 \sim-21.0$ and $-24.5 \sim-21.0 \%$ respectively, representing a mixture of organic source from terrestrial plants and marine algae.

Based on the discussion above, we further compare the $\delta^{13} \mathrm{C}$ and TOC/TN values of sedimentary organics from 
sites STD235 and ZSQD289 with the suspended particles of rivers and surface sediments from southwestern Taiwan offshore and China continent (Fig. 6). Such a comparison must take into account the difference of isotopic composition of atmospheric $\mathrm{CO}_{2}$ between Quaternary and present. The present isotopic composition of $\mathrm{CO}_{2}$ is $7.8 \%$ while the preindustrial value was about $1-1.5 \%$ heavier without significant difference during geological times, except sharp variation at era boundaries (Schlanger et al. 1987; Shackleton 1987; Marino and McElroy 1991; Eggleston et al. 2016).

Accordingly, corrective value of $+1.5 \%$ o has been applied to modern suspended particles and surface sediment organic isotopes in order to allow for a better comparison with SCS sediments (Fig. 6). The geochemical characteristics of both cores are similar to the sedimentary organic matters from southwestern Taiwan offshore. According to previous study, abundant terrigenous organic matters in northeastern SCS are from SW Taiwan Rivers, and a majority of those river-borne particles are exported away from the shelf and slope region and was transported directly into the deep-sea basin through submarine canyon (Hsu et al. 2014). Selvaraj et al. (2015) made use of the stable isotopic and biomarker evidence to research the terrigenous organics in deep sea off southwestern Taiwan, and also found rapid transport of terrigenous organic matter into the deep sea during tropic storms. Thus, it is possible that the sedimentary organic matter of site ZSQD289 in deep-sea basin is directly input from southwestern Taiwan submarine canyon. On the other hand, the sediments transportation is controlled by compli- cated current system. Compared with the site ZSQD289, the core STD235 was more likely to be affected by deep water current according to prior analysis. Studies of pollen and foraminiferal $\delta^{13} \mathrm{C}$ distribution patterns also indicate that there are strong and extended water current via the Bashi Strait to SCS (Sun and Li 1999; Wang et al. 1999). Therefore, it is inferred that SCS deep water current, probably originating a branch of the southward North Pacific deep water, intruded the SCS through the Bashi Strait and transported sedimentary organic matters from southern Taiwan to the site of STD235. Thus similar organic geochemical characteristics between the core STD235 and southwestern Taiwan offshore may indicate that the terrestrial organic matters supply from SW Taiwan have an important contribution to our study site. However, it is noteworthy that different sediment erosion and depositional rate may also influence geochemical characteristics in the sediment organic matters. Because of lacking direct evidence, it is unable to exclude the fossil and petrogenic carbon sources. So the sedimentary organic matter in the study sites may be not only derived from Taiwan but from other sources, which is respecting for further research.

\subsection{Organic Geochemical Information along Core Columns: Implication to Paleoenvironment}

From the last glacial to Holocene was not a smooth transition from one climate state to another, but rather occurred in a series of abrupt warming steps interrupted by (a)

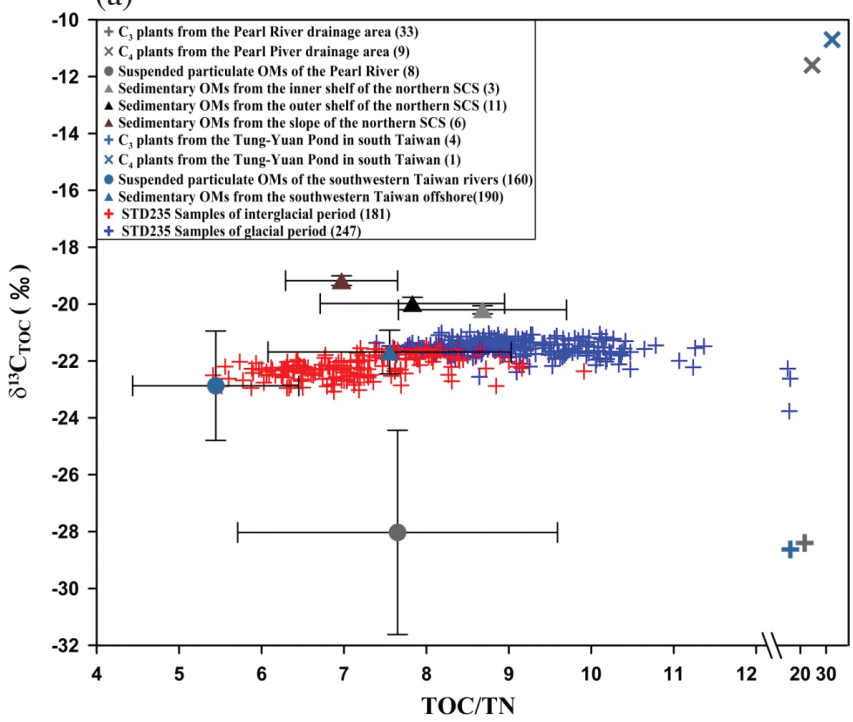

(b)

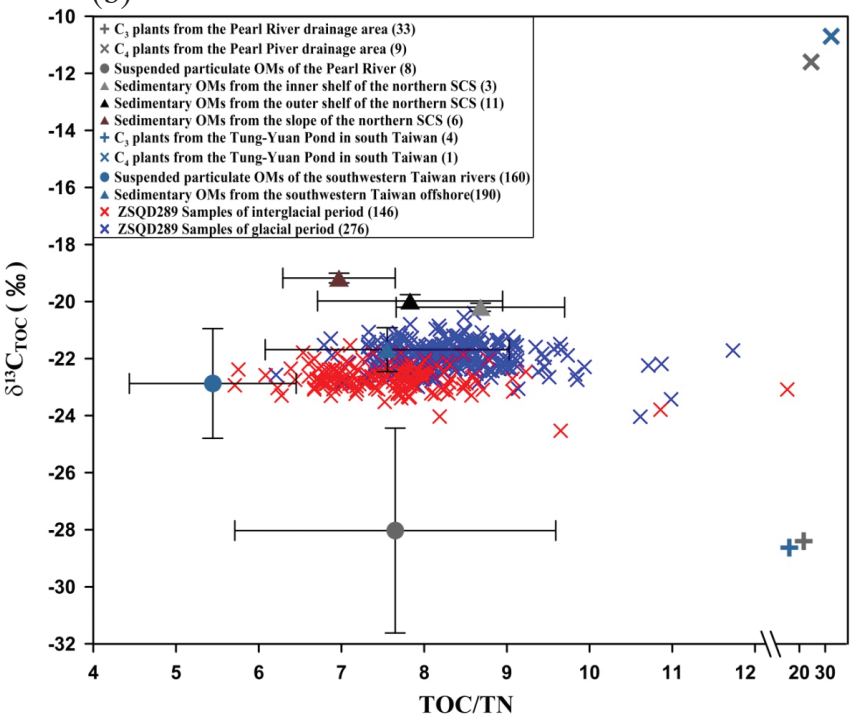

Fig. 6. $\delta^{13} \mathrm{C}$ and TOC/TN plots of STD235 (a) and ZSQD289 (b) cores, compared with $\mathrm{C}_{3}, \mathrm{C}_{4}$ plants, Taiwan and Pearl River sources. (Error bars showing the standard deviation; $\delta^{13} \mathrm{C}$ values of both cores were corrected by the difference between ancient and modern atmospheric $\mathrm{CO}_{2}$, see discussion in the text). Data of $\mathrm{C}_{3}, \mathrm{C}_{4}$ plants of Pearl River from Yu et al. (2010), and those of south Taiwan from Yang et al. (2011b); data of suspended/sedimentary organic matters (OMs) of Pearl River, and slope and shelf of northern SCS (NSCS) from Zhang et al. (2014), data of suspended/sedimentary OMs in SW Taiwan rivers from Hilton et al. (2010), and SW Taiwan offshore from Hsu et al. (2014). Inside the legend box, the numbers in the brackets represent the sample numbers used for the data compilations. 
sudden shifts toward near-glacial conditions (Dansgaard et al. 1993). Thus, the high resolution sediment records during this period can be used for precisely understanding the relationship between individual environmental variation in northeastern SCS and global climate change. Based on the high-resolution TOC, TOC/TN, and $\delta^{13} \mathrm{C}$ records with accurate $\mathrm{AMS}^{14} \mathrm{C}$ and $\delta^{18} \mathrm{O}$ of planktonic foraminifera dating of the core STD235 and ZSQD289, this study reconstruct the paleoenvironment changes in terms of terrestrial input, marine authigenic productivity and monsoon evolution as well as abrupt climatic events during the past $30 \mathrm{ka}$ in northeastern SCS.

\subsubsection{Pre-Last Glacial Maximum (Pre-LGM)}

Reconstruction of relative sea level suggested repeated transgression during MIS3 and the rapidly sea level dropping by $\sim 90 \mathrm{~m}$ after $30 \mathrm{ka}$ BP (Lambeck and Chappell 2001). $\mathrm{TOC} / \mathrm{TN}$ ratios during this time fluctuate obviously in higher value, and exhibit a weak positive correlation with decreased $\delta^{13} \mathrm{C}$ (Fig. 7), suggesting that terrestrial organic supply was somewhat enhanced. During Pre-LGM, the climatic condition was cold and relatively wet, as well as woodland was dominated and grasses generally in low abundance in Taiwan (Li et al. 2013). Although our data about herb pollen content show an increase of herbaceous plant, the percentage of woodland is still high, around in the range of $68-98 \%$. Thus, the terrestrial organic supply is primary woodland during this period (mostly $\mathrm{C}_{3}$ plants, the carbon isotope composition in the range of -37 to $-20 \%$ ) (O'Leary 1988). The exposure of the continental shelf favored direct transfer of coastal and riverine sediments to the deep ocean following the sea level rapid falling by $\sim 90 \mathrm{~m}$, without distinct temporary storage or partial remineralization on shelves and thus showing a better burial efficiency. So the increased fluvial sediments supply and enhanced terrestrial depleted $\delta^{13} \mathrm{C}$ dilution caused the $\delta^{13} \mathrm{C}$ approaching to more negative values (Fig. 7). Low $\delta^{15} \mathrm{~N}$ values during this period may coincide with a pronounced fall in sea level from fast ice build-up. Furthermore, it is reported that depleted $\delta^{15} \mathrm{~N}$ in sediments

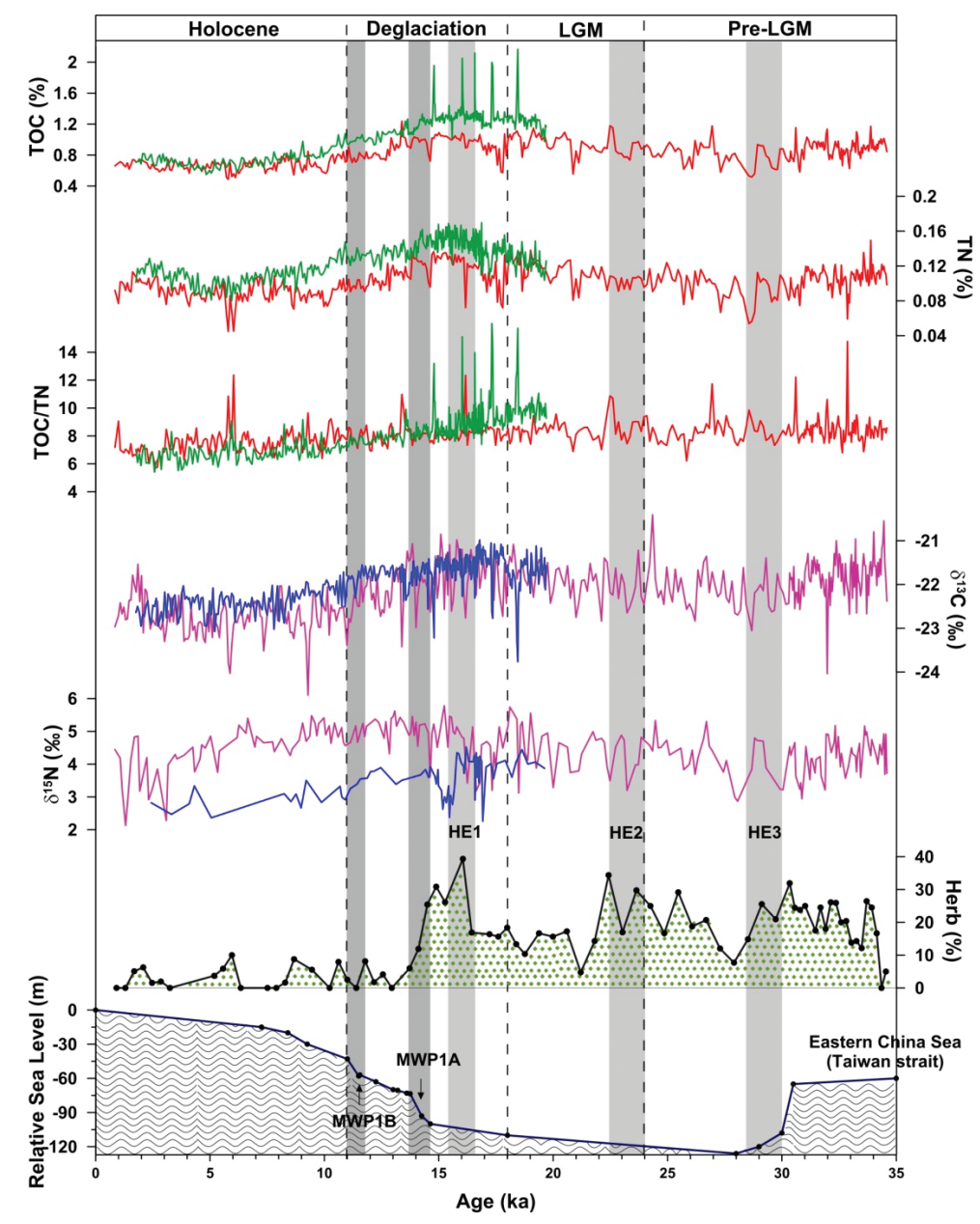

Fig. 7. Site STD235 and ZSQD289 down core profiles of abundance in TOC and TN, TOC/TN weight ratios, $\delta^{13} \mathrm{C}$ and $\delta^{15} \mathrm{~N}$ values in bulk sediment (the green and blue curve for STD235, the red and deep rose curve for ZSQD289), comparison with herb pollen content (a percentage of total herb and woodland pollen) of ZSQD289 (Yang et al. 2015) and the relative sea level (Lambeck and Chappell 2001; Lambeck et al. 2002). 
might represent increased nitrogen fixation (Biscaye et al. 1997), and the enhanced nitrogen fixation was derived from flouring Trichodesmium during cooling MIS 3, as reflected in the reduced $\delta^{15} \mathrm{~N}$ values in Fig. 7 .

\subsubsection{LGM}

The time interval of $24 \sim 18 \mathrm{ka}$ BP corresponds to the LGM. During this interval TOC and TN concentration gradually increase, but TOC/TN ratios are almost invariant except a few excursion. High TOC in deep-sea sediment during LGM has been found in the equatorial Atlantic, equatorial Pacific as well as low latitudes sea (Pedersen 1983; Lyle 1988; Sarnthein et al. 1988). The enhanced burial of organic carbon in glacial period sediments was interpreted as reflecting increased terrestrial organic matter input and the increased biological productivity accompanying intensified wind-driven upwelling, better burial and preservation under reduced oxygenation (Pedersen 1983; Bradtmiller et al. 2010). A higher dust supply by prevailing winter monsoon and intensified wind-driven upwelling could provide an additional increase of primary biomass production. In this study, the increased TOC and TN concentrations while almost invariant TOC/TN ratios may be the result of markedly increased marine authigenic productivity, which may have offset the increased terrestrial organic input resulting from sea level falling during LGM.

Based on analysis of TOC, TN concentrations and TOC/TN ratios, the increased $\delta^{13} \mathrm{C}$ values during LGM (Fig. 7) may be correlated with elevated marine primary production. As atmospheric $\mathrm{pCO}_{2}$ was low during LGM, more $\mathrm{CO}_{2}$ dissolved in the ocean and higher oceanic primary productivity was achieved, as a result the values of $\delta^{13} \mathrm{C}$ increased by $2 \%$ at most in the records from SCS during glacial period (Kienast et al. 2001; Eggleston et al. 2016). According to previous study on terrestrial vegetation of land areas adjacent to SCS, there was a greater extent of herbaceous vegetation (mostly $\mathrm{C}_{4}$ plants, the carbon isotope composition in the range of -14 to $-9 \%$ ) and a recession of woodland with depleted $\delta^{13} \mathrm{C}$ during LGM (O'Leary 1988; Fairbanks 1989; Luo et al. 2005; Zhou et al. 2012). So the heterogeneous terrestrial vegetation may be an alternative explanation to the $\delta^{13} \mathrm{C}$ distribution features, as the pollen data also show an increased herbaceous contribution during this period compared to present shown in Fig. 7.

$\delta^{15} \mathrm{~N}$ values have similar increased trend along with $\delta^{13} \mathrm{C}$ during LGM (Fig. 7). In the northern SCS, the entire upwelling nitrate was utilized on an annual basis, and as a consequence, this documented change in phytoplankton abundance and utilization did not evidently leave an isotopic signature on the average annual $\delta^{15} \mathrm{~N}$ value of particulate organic nitrogen (Altabet et al. 1995). If nitrate utilization was incomplete, then glacial increased dustiness would have been likely to cause the elevated $\delta^{15} \mathrm{~N}$ due to preferential fractionation (Higginson et al. 2003).

\subsubsection{Deglaciation}

The time interval of 18 - $11 \mathrm{ka} \mathrm{BP}$ between LGM and Holocene corresponds to the deglaciation. Figure 7 illustrates in details a stepped response in TOC, TN and $\delta^{13} \mathrm{C}$ during deglaciation, which shows a strong correlation to sea level variation. The parameters of TOC and TN, as well as $\delta^{13} \mathrm{C}$ and $\delta^{15} \mathrm{~N}$ are all sharply changed during 18 - $17.5 \mathrm{ka} \mathrm{BP}$ through a short transition to the deglaciation (in the core of ZSQD289, Fig. 7). And then they turned to higher values for the next $3 \mathrm{ka}$ in both cores until around $14 \mathrm{ka} \mathrm{BP}$, except for a few excursions which corresponded to the fluctuation of herb pollen content and sea level rising (Fig. 7). During 18 - $11 \mathrm{ka} \mathrm{BP}$, terrestrial supply decrease is reflected by TOC/ $\mathrm{TN}$ variations as a result of rapid sea level rising and winter monsoon weakening. On the other hand, the herb pollen content in the core ZSQD289 sharply decreased during 15 $13 \mathrm{ka} \mathrm{BP}$ and then kept low values, corresponding with $\delta^{13} \mathrm{C}$ gradually decreasing since $15 \mathrm{ka} \mathrm{BP}$, which might indicate the organic matter from woody plant increased. Meanwhile the data of pollen, $\delta{ }^{13} \mathrm{C}$ and $n$-alkane- $\delta \mathrm{D}$ from Toushe basin also showed that $\mathrm{C}_{3}$ plant have occupied in central Taiwan at this time (Li et al. 2013).

There are total five obvious lower $\delta^{13} \mathrm{C}$ excursions respectively corresponding to five higher TOC and TOC/TN excursions observed in STD235 sediments during 18 - 14.5 ka BP (Fig. 7). Generally, a negative shift in $\delta^{13} \mathrm{C}$ concurrent with positive shifts in TOC and TOC/TN in sediments can be indicative of terrigenous organic increase (Das et al. 2013). Shintani et al. (2011) examined terrestrial biomarkers such as n-alkanes and n-fatty acids and generated a record of TEX86-derived sea surface temperatures over the last 28 ka for core MD97-2146 (near core 17940) from the northern SCS. The concentration of long-chain n-alkanes and n-fatty acids fluctuating in high values over $20-15 \mathrm{ka}$ for core MD97-2146 also indicate the increase of terrigenous input at that time. The change in TEX86-derived sea surface temperature at core MD97-2146 (near core 17940) corresponding to the variation in Chinese stalagmite $\delta^{18} \mathrm{O}$ during deglaciation (Wang et al. 2002; Yuan et al. 2004; Shintani et al. 2011) reflected atmospheric and oceanic reorganization on a millennial timescale in this period. A considerable change in terrestrial sediment delivery occurred at $\sim 14-15 \mathrm{ka} \mathrm{BP}$. Terrestrial organic matter was presumably supplied by enhanced aeolian transportation prior to $\sim 14-15 \mathrm{ka}$ BP. But the contribution from river discharge becoming more important thereafter presumably due to intensified summer monsoon (Shintani et al. 2011). Five fluctuations of terrigenous input recorded in the core STD235 during deglaciation may be a regional response to that transition. Perhaps because of different sedimentary environment, however, the similar strong excursions are not distinctly observed in ZSQD289. 


\subsubsection{Holocene}

At sites STD235 and ZSQD289, TOC/TN ratios indicate a low input of terrestrial organic material throughout the Holocene. Since around $14 \mathrm{ka} \mathrm{BP}$, the contribution from river discharge become more important presumably due to intensified summer monsoon (Wang 1999; Shintani et al. 2011). However, the flooded continental shelves due to high sea level caused by ice volume contraction would lengthen the distance between river mouth and deposition location. Consequently, less continental material would be deposited at our study sites. Therefore, low TOC/TN ratios during Holocene may be correlated with high sea level accompanied by weak winter monsoon and enhanced summer monsoon. The enhanced carbon isotopic fractionation of phytoplankton with increased atmospheric $\mathrm{pCO}_{2}$ may be the primary mechanism to determine $\delta^{13} \mathrm{C}$ during the Holocene (Kienast et al. 2001).

During Holocene, there existed a weak correlative relationship between the decreased $\delta^{15} \mathrm{~N}$ values and the decreased $\delta^{18} \mathrm{O}$ in the Holocene (Fig. 3), which probably reflected a gradual intensification of summer monsoon precipitation. The gradual $\delta^{15} \mathrm{~N}$ depletion trend was also recorded in the Holocene sediments at nearby cores ODP1144 and 17940 (Kienast 2000; Higginson et al. 2003), implying a regional $\delta^{15} \mathrm{~N}$ depletion during Holocene. Higginson et al. (2003) suggested that depleted $\delta^{15} \mathrm{~N}$ values during Holocene likely result from an intensified local $\mathrm{N}$ fixation in surface water, and from the reduction of deep-water exchange with west pacific intermediate water. Similar $\delta^{15} \mathrm{~N}$ distribution trend was also recorded in Santa Barbara basin and Mexican Margin sites (Emmer and Thunell 2000; Ganeshram et al. 2000), indicating a global Holecene signature.

\section{CONCLUSIONS}

Since the last glacial period, the sedimentation rates of sites STD235 and ZSQD289 are characterized by higher rate in glacial than interglacial period, which is controlled by terrigenous input. Furthermore, STD235 site may be affected by deep water current which is correlated to sea-level change and formed sedimentary drift with a high sedimentation rate at times, while the core ZSQD289 may be less influenced by deep water current. In general, high accumulation-rate sediments results from the combined actions of both deep-water current and terrigenous supply.

The clay mineral assemblages and organic geochemical characteristics of cores STD235 and ZSQD289 indicate that the terrestrial sediments from SW Taiwan make significant contribution to both sites. On the other hand, organic geochemical characteristics show that the provenance of sedimentary organic matters is a mixture of marine and terrestrial sources. Moreover, it is possible that the sedimentary organic matter of site ZSQD289 in deep-sea basin is di- rectly input from southwestern Taiwan submarine canyon, while the sedimentary organic matter in the core STD235 was probably transported by deep water current.

During Pre-LGM, high TOC/TN ratios and decreased $\delta^{13} \mathrm{C}$ values indicate that terrestrial organic supply is enhanced. Low $\delta^{15} \mathrm{~N}$ values may be a signal of increased nitrogen fixation with cooling and coincided with a pronounced sea level fall. In the period of $\mathrm{LGM}, \mathrm{TOC}, \mathrm{TN}, \delta^{13} \mathrm{C}$, and $\delta^{15} \mathrm{~N}$ values gradually increase, but TOC/TN ratios are almost invariant except for a few excursions, reflecting an increased marine primary biomass production. Between 18 - $11 \mathrm{ka} \mathrm{BP}$ was a transition from LGM to Holocene, which is associated with a strong climatic fluctuation correlated to sea level variations. TOC/TN ratios and $\delta^{13} \mathrm{C}$ values generally present a decreased trend, indicating reduced terrestrial organic supply and marine primary production due to rapid sea level rising and winter monsoon weakening. Several abrupt climatic events may be regional response to the transition of climate and ocean system on a millennial timescale during this period. The positive correlation between $\delta^{13} \mathrm{C}$ and TOC/TN ratios is observed during Holocene. Low $\mathrm{TOC} / \mathrm{TN}$ ratios indicate reduced input of terrestrial organic material, and decreased $\delta^{13} \mathrm{C}$ is primarily constrained by carbon isotopic fractionation of enhanced phytoplankton.

Acknowledgements We are grateful to the reviewers for the careful reviews to our manuscript, which greatly improved earlier drafts of the manuscript. Many thanks to Dr. Lekan Faboya who has helped to polish the English writing. This work was supported financially by the National Natural Science Foundation of China (grant number 41303056).

\section{REFERENCES}

Altabet, M. A., R. Francois, D. W. Murray, and W. L. Prell, 1995: Climate-related variations in denitrification in the Arabian Sea from sediment ${ }^{15} \mathrm{~N} /{ }^{14} \mathrm{~N}$ ratios. Nature, 373, 506-509, doi: 10.1038/373506a0. [Link]

An, Z. S., T. S. Liu, Y. C. Lu, S. C Porter, G. Kukla, X. H. Wu, and Y. M. Hua, 1990: The long-term paleomonsoon variation recorded by the loess-paleosol sequence in Central China. Quat. Int., 7-8, 91-95, doi: 10.1016/1040-6182(90)90042-3. [Link]

Arnaboldi, M. and P. A. Meyers, 2006: Patterns of organic carbon and nitrogen isotopic compositions of latest Pliocene sapropels from six locations across the Mediterranean Sea. Palaeogeogr. Palaeoclimatol. Palaeoecol.,235,149-167, doi: 10.1016/j.palaeo.2005.09.027. [Link]

Biscaye, P. E., 1965: Mineralogy and Sedimentation of Recent Deep-Sea Clay in the Atlantic Ocean and Adjacent Seas and Oceans. Geol. Soc. Am. Bull., 76, 803832, doi: 10.1130/0016-7606(1965)76[803:MASORD ]2.0.CO;2. [Link] 
Biscaye, P. E., F. E. Grousset, M. Revel, S. Van Der Gaast, G. A. Zielinski, A. Vaars, and G. Kukla, 1997: Asian provenance of glacial dust (stage 2) in the Greenland Ice Sheet Project 2 ice core, Summit, Greenland. J. Geophys. Res., 102, 26765-26781, doi: 10.1029/97JC01249. [Link]

Boulay, S., C. Colin, A. Trentesaux, F. Pluquet, J. Bertaux, T. Blamart, C. Buehring, and P. X. Wang, 2003: Mineralogy and sedimentology of Pleistocene sediment in the South China Sea (ODP Site 1144). In: Prell, W. L., P. Wang, P. Blum, D. K. Rea, and S. C. Clemens (Eds.), Proceedings of the Ocean Drilling Program, Scientific Results, Vol. 184, 1-21, doi: 10.2973/odp. proc.sr.184.211.2003. [Link]

Boulay, S., C. Colin, A. Trentesaux, N. Frank, and Z. Liu, 2005: Sediment sources and East Asian monsoon intensity over the last $450 \mathrm{ky}$. Mineralogical and geochemical investigations on South China Sea sediments. Palaeogeogr. Palaeoclimatol. Palaeoecol., 228, 260277, doi: 10.1016/j.palaeo.2005.06.005. [Link]

Bradtmiller, L. I., R. F. Anderson, J. P. Sachs, and M. Q. Fleisher, 2010: A deeper respired carbon pool in the glacial equatorial Pacific Ocean. Earth Planet. Sci. Lett., 299, 417-425, doi: 10.1016/j.eps1.2010.09.022. [Link]

Bühring, C., M. Sarnthein, and H. Erlenkeuser, 2004: Toward a high-resolution stable isotope stratigraphy of the last 1.1 million years: Site 1144, South China Sea. In: Prell, W. L., P. Wang, P. Blum, D. K. Rea, and S. C. Clemens (Eds.), Proceeding of the Ocean Drilling Program, Scientific Results, Vol. 184, 1-14, doi: 10.2973/ odp.proc.sr.184.205.2004. [Link]

Burnett, A. P., M. J. Soreghan, C. A. Scholz, and E. T. Brown, 2011: Tropical East African climate change and its relation to global climate: A record from Lake Tanganyika, Tropical East Africa, over the past 90+ kyr. Palaeogeogr. Palaeoclimatol. Palaeoecol., 303, 155-167, doi: 10.1016/j.palaeo.2010.02.011. [Link]

Castro, D. F., D. de Fátima Rossetti, and L. C. Ruiz Pessenda, 2010: Facies, $\delta^{13} \mathrm{C}, \delta^{15} \mathrm{~N}$ and $\mathrm{C} / \mathrm{N}$ analyses in a late Quaternary compound estuarine fill, northern Brazil and relation to sea level. Mar. Geol., 274, 135-150, doi: 10.1016/j.margeo.2010.03.011. [Link]

Chuang, C. Y. and H. S. Yu, 2002: Morphology and canyon forming processes of upper reach of the Penghu submarine canyon off Southwestern Taiwan. Terr. Atmos. Ocean. Sci., 13, 91-108, doi: 10.3319/ TAO.2002.13.1.91(O). [Link]

Clift, P. D., S. M. Wan, and J. Blusztajn, 2014: Reconstructing chemical weathering, physical erosion and monsoon intensity since $25 \mathrm{Ma}$ in the northern South China Sea: A review of competing proxies. Earth-Sci. Rev., 130, 86-102, doi: 10.1016/j.earscirev.2014.01.002. [Link]

Dadson, S. J., N. Hovius, H. Chen, W. B. Dade, M. L.
Hsieh, S. D. Willett, J. C. Hu, M. J. Horng, M. C. Chen, C. P. Stark, D. Lague, and J.-C. Lin, 2004: Links between erosion, runoff variability and seismicity in the Taiwan orogen. Nature, 426, 648-651, doi: 10.1038/ nature 02150 . [Link]

Dai, L., C. Y. Weng, and L. M. Mao, 2015: Patterns of vegetation and climate change in the northern South China Sea during the last glaciation inferred from marine palynological records. Palaeogeogr. Palaeoclimatol. Palaeoecol., 440, 249-258, doi: 10.1016/j. palaeo.2015.08.041. [Link]

Dansgaard, W. S., S. J. Johnsen, H. B. Clausen, D. DahlJensen, N. S. Gundestrup, C. U. Hammer, C. S. Hvidberg, J. P. Steffensen, A. E. Sveinjörnsdottir, J. Jouzel, and G. Bond, 1993: Evidence for general instability of past climate from a 250-kyr ice-core record. Nature, 364, 218-220, doi: 10.1038/364218a0. [Link]

Das, O., Y. Wang, J. Donoghue, X. Xu, J. Coor, J. Elsner, and Y. Xu, 2013: Reconstruction of paleostorms and paleoenvironment using geochemical proxies archived in the sediments of two coastal lakes in northwest Florida. Quat. Sci. Rev., 68, 142-153, doi: 10.1016/j. quascirev.2013.02.014. [Link]

Deines, P., 1980: The isotopic composition of reduced organic carbon. Handbook of Environmental Isotope Geochemistry, Vol. 1, 329-406, doi: 10.1016/b978-0444-41780-0.50015-8. [Link]

Eggleston, S., J. Schmitt, B. Bereiter, R. Schneider, and H. Fischer, 2016: Evolution of the stable carbon isotope composition of atmospheric $\mathrm{CO}_{2}$ over the last glacial cycle. Paleoceanography, 31, 434-452, doi: 10.1002/2015PA002874. [Link]

Emmer, E. and R. C. Thunell, 2000: Nitrogen isotope variations in Santa Barbara Basin sediments: Implications for denitrification in the eastern tropical North Pacific during the last 50,000 years. Paleoceangraphy, 15, 377-387, doi: 10.1029/1999PA000417. [Link]

Fairbanks, R. G., 1989: A 17,000-year glacio-eustatic sea level record: influence of glacial melting rates on the Younger Dryas event and deep-ocean circulation. $\mathrm{Na}$ ture, 342, 637-642, doi: 10.1038/342637a0. [Link]

Ganeshram, R. S., T. F. Pedersen, S. E. Calvert, G. W. Mcneill, and M. R. Fontugne, 2000: Glacial-interglacial variability in denitrification in the world's oceans: Causes and consequences. Paleoceangraphy, 15, 361376, doi: 10.1029/1999PA000422. [Link]

Guo, Z. T., P. Biscaye, L. Y. Wei, X. H. Chen, S. Z. Peng, and T. S. Liu, 2000: Summer monsoon variations over the last 1.2 Ma from the weathering of loess-soil sequences in China. Geophys. Res. Lett., 27, 1751-1754, doi: 10.1029/1999GL008419. [Link]

He, J., M. X. Zhao, L. Li, P. X. Wang, and H. M. Ge, 2008: Sea surface temperature and terrestrial biomarker records of the last $260 \mathrm{ka}$ of core MD05-2904 from the 
northern South China Sea. Chi. Sci. Bull., 53, 23762384, doi: 10.1007/s11434-008-0289-2. [Link]

Hedges, J. I. and J. M. Oades, 1997: Comparative organic geochemistries of soils and marine sediments. Org. Geochem., 27, 319-361, doi: 10.1016/S01466380(97)00056-9. [Link]

Higginson, M. J., J. R. Maxwell, and M. A. Altabet, 2003: Nitrogen isotope and chlorin paleoproductivity records from the Northern South China Sea: remote vs. local forcing of millennial- and orbital-scale variability. Mar. Geol., 201, 223-250, doi: 10.1016/S00253227(03)00218-4. [Link]

Hilton, R. G., A. Galy, N. Hovius, M. J. Horng, and H. Chen, 2010: The isotopic composition of particulate organic carbon in mountain rivers of Taiwan. Geochim. Cosmochim. Acta, 74, 3164-3181, doi: 10.1016/j. gca.2010.03.004. [Link]

Hsu, F. H., C. C. Su, C. H. Wang, S. Lin, J. Liu, and C. A. Huh, 2014: Accumulation of terrestrial organic carbon on an active continental margin offshore southwestern Taiwan: Source-to-sink pathways of river-borne organic particles. J. Asian Earth Sci., 91, 163-173, doi: 10.1016/j.jseaes.2014.05.006. [Link]

Hu, J. F., P. A. Peng, G. D. Jia, B. X. Mai, and G. Zhang, 2006: Distribution and sources of organic carbon, nitrogen and their isotopes in sediments of the subtropical Pearl River estuary and adjacent shelf, Southern China. Mar. Chem., 98, 274-285, doi: 10.1016/j. marchem.2005.03.008. [Link]

Huang, B. Q., Z. M. Jian, and P. X. Wang, 2005: Paleoceanographic evolution recorded in the northern South China Sea since 4 Ma. Sci. China Ser. D, 48, 2166-2173, doi: 10.1360/03yd0564. [Link]

Hung, J. J., Y. T. Yeh, and C. A. Huh, 2012: Efficient transport of terrestrial particulate carbon in a tectonically-active marginal sea off southwestern Taiwan.Mar. Geol., 315-318, 29-43, doi: 10.1016/j.margeo.2012.05.006. [Link]

Jia, G. D., P. A. Peng, Q. H. Zhao, and Z. M. Jian, 2003: Changes in terrestrial ecosystem since $30 \mathrm{Ma}$ in East Asia: Stable isotope evidence from black carbon in the South China Sea. Geology, 31, 1093-1096, doi: 10.1130/G19992.1. [Link]

Jian, Z. M., Q. H. Zhao, X. R. Cheng, J. L. Wang, P. X. Wang, and X. Su, 2003: Pliocene-Pleistocene stable isotope and paleoceanographic changes in the northern South China Sea. Palaeogeogr. Palaeoclimatol. Palaeoecol., 193, 425-442, doi: 10.1016/S00310182(03)00259-1. [Link]

Kienast, M., 2000: Unchanged nitrogen isotopic composition of organic matter in the South China Sea during the last climatic cycle: Global implications. Paleoceanography, 15, 244-253, doi: 10.1029/1999PA000407. [Link]
Kienast, M., S. E. Calvert, C. Pelejero, and J. O. Grimalt, 2001: A critical review of marine sedimentary $\delta^{13} \mathrm{C}_{\mathrm{org}}$ $\mathrm{pCO}_{2}$ estimates: New palaeorecords from the South China Sea and a revisit of other low-latitude $\delta^{13} \mathrm{Corg}$ $\mathrm{pCO}_{2}$ records. Global Biogeochem. Cycles, 15, 113127, doi: 10.1029/2000GB001285. [Link]

Lamb, A. L., G. P. Wilson, and M. J. Leng, 2006: A review of coastal palaeoclimate and relative sea-level reconstructions using $\delta^{13} \mathrm{C}$ and $\mathrm{C} / \mathrm{N}$ ratios in organic material. Earth-Sci. Rev., 75, 29-57, doi: 10.1016/j. earscirev .2005.10.003. [Link]

Lambeck, K. and J. Chappell, 2001: Sea level change through the last glacial cycle. Science, 292, 679-686, doi: 10.1126/science.1059549. [Link]

Lambeck, K., Y. Yokoyama, and T. Purcell, 2002: Into and out of the Last Glacial Maximum: sea-level change during Oxygen Isotope Stages 3 and 2. Quat. Sci. Rev., 21, 343-360, doi: 10.1016/S0277-3791(01)00071-3. [Link]

Li, H. C., P. M. Liew, O. Seki, T. S. Kuo, K. Kawamura, L. C. Wang, and T. Q. Lee, 2013: Paleoclimate variability in central Taiwan during the past $30 \mathrm{Kyrs}$ reflected by pollen, $\delta^{13} C_{\mathrm{TOC}}$, and $n$-alkane- $\delta \mathrm{D}$ records in a peat sequence from Toushe Basin. J. Asian Earth Sci., 69, 166-176, doi: 10.1016/j.jseaes.2012.12.005. [Link]

Lin, D. C., C. H. Liu, T. H. Fang, C. H. Tsai, M. Murayama, and M. T. Chen, 2006: Millennial-scale changes in terrestrial sediment input and Holocene surface hydrography in the northern South China Sea (IMAGES MD972146). Palaeogeogr. Palaeoclimatol. Palaeoecol., 236, 56-73, doi: 10.1016/j.palaeo.2005.11.039. [Link]

Lisitzin, A. P., 1972: Sedimentation in the World Ocean, Society of Economic Paleontologists and Mineralogists Special Publication Press, 35 pp.

Liu, J. G., R. Xiang, M. H. Chen, Z. Chen, W. Yan, and F. Liu, 2011: Influence of the Kuroshio current intrusion on depositional environment in the Northern South China Sea: Evidence from surface sediment records. Mar. Geol., 285, 59-68, doi: 10.1016/j.margeo.2011.05.010. [Link]

Liu, J. G., R. Xiang, Z. Chen, M. H. Chen, W. Yan, L. L. Zhang, and H. Chen, 2013: Sources, transport and deposition of surface sediments from the South China Sea. Deep-Sea Res. Part I-Oceanogr. Res. Pap., 71, 92-102, doi: 10.1016/j.dsr.2012.09.006. [Link]

Liu, Z. F., A. Trentesaux, S. C. Clemens, C. Colin, P. X. Wang, B. Q. Huang, and S. Boulay, 2003: Clay mineral assemblages in the northern South China Sea: Implications for East Asian monsoon evolution over the past 2 million years. Mar. Geol., 201, 133-146, doi: 10.1016/S0025-3227(03)00213-5. [Link]

Liu, Z. F., S. T. Tuo, C. Colin, J. T. Liu, C. Y. Huang, K. Selvaraj, C. T. A. Chen, Y. L. Zhao, F. P. Siringan, S. 
Boulay, and Z. Chen, 2008: Detrital fine-grained sediment contribution from Taiwan to the northern South China Sea and its relation to regional ocean circulation. Mar. Geol., 255, 149-155, doi: 10.1016/j.margeo.2008.08.003. [Link]

Liu, Z. F., C. Colin, X. J. Li, Y. L. Zhao, S. T. Tuo, Z. Chen, F. P. Siringan, J. T. Liu, C. Y. Huang, C. F. You, and K. F. Huang, 2010: Clay mineral distribution in surface sediments of the northeastern South China Sea and surrounding fluvial drainage basins: Source and transport. Mar. Geol., 277, 48-60, doi: 10.1016/j.margeo.2010.08.010. [Link]

Louchouarn, P., M. Lucotte, and N. Farella, 1999: Historical and geographical variations of sources and transport of terrigenous organic matter within a large-scale coastal environment. Org. Geochem., 30, 675-699, doi: 10.1016/S0146-6380(99)00019-4. [Link]

Lu, L.F., J. G. Cai, Y. J. Bao, C. X. Li, S. Y. Yang, and D. D. Fan, 2006: Summary of processes and significance of clay minerals in marine sedimentary organic matter preservation and in global carbon cycle. $A d v$. Earth Sci., 21, 931-937, doi: 10.3321/j.issn:10018166.2006.09.007. [Link]

Lüdmann, T., H. K. Wong, and K. Berglar, 2005: Upward flow of North Pacific Deep Water in the northern South China Sea as deduced from the occurrence of drift sediments. Geophys. Res. Lett., 32, 215-236, doi: 10.1029/2004GL021967. [Link]

Luo, Y. L., X. J. Sun, and Z. M. Jian, 2005: Environmental change during the penultimate glacial cycle: a highresolution pollen record from ODP Site 1144, South China Sea. Mar. Micropaleontol., 54, 107-123, doi: 10.1016/j.marmicro.2004.09.006. [Link]

Lyle, M., 1988: Climatically forced organic carbon burial in equatorial Atlantic and Pacific Oceans. Nature, 335, 529-532, doi: 10.1038/335529a0. [Link]

Marino, B. D. and M. B. McElroy, 1991: Isotopic composition of atmospheric $\mathrm{CO}_{2}$ inferred from carbon in $\mathrm{C}_{4}$ plant cellulose. Nature, 349, 127-131, doi: 10.1038/349127a0. [Link]

Marthur, J. M., R. V. Tyson, J. Thomson, and D. Mattey, 1992: Early diagenesis of marine organic matter: Alteration of the carbon isotopic composition. Mar. Geol., 105, 51-61, doi: 10.1016/0025-3227(92)90181-G. [Link]

Martinelli, L. A., M. C. Piccolo, A. R. Townsend, P. M. Vitousek, E. Cuevas, W. McDowell, G. P. Robertson, O. C. Santos, and K. Treseder, 1999: Nitrogen stable isotopic composition of leaves and soil: Tropical versus temperate forests. Biogeochemistry, 46, 45-65, doi: 10.1007/BF01007573. [Link]

Meyers, P. A., 1994: Preservation of elemental and isotopic source identification of sedimentary organic matter. Chem. Geol., 114, 289-302, doi: 10.1016/00092541(94)90059-0. [Link]
Meyers, P. A., 1997: Organic geochemical proxies of paleoceanographic, paleolimnologic, and paleoclimatic processes. Org. Geochem., 27, 213-250, doi: 10.1016/ S0146-6380(97)00049-1. [Link]

Meyers, P. A., 2003: Applications of organic geochemistry to paleolimnological reconstructions: A summary of examples from the Laurentian Great Lakes. Org. Geochem., 34, 261-289, doi: 10.1016/S01466380(02)00168-7. [Link]

Milliman, J. D. and J. P. M. Syvitski, 1992: Geomorphic/ Tectonic Control of Sediment Discharge to the Ocean: The Importance of Small Mountainous Rivers. J. Geol., 100, 525-544, doi: 10.1086/629606. [Link]

Morley, J. J. and L.E. Heusser, 1997: Role of orbital forcing in east Asian monsoon climates during the last $350 \mathrm{kyr}$ : Evidence from terrestrial and marine climate proxies from core RC14-99. Paleoceanography, 12, 483-493, doi: 10.1029/97PA00213. [Link]

Nijenhuis, I. A. and G. J. de Lange, 2000: Geochemical constraints on Pliocene sapropel formation in the eastern Mediterranean. Mar. Geol., 163, 41-63, doi: 10.1016/ S0025-3227(99)00093-6. [Link]

O'Leary, M. H., 1988: Carbon Isotopes in Photosynthesis. BioScience, 38, 328-336, doi: 10.2307/1310735. [Link]

Pedersen, T. F., 1983: Increased productivity in the eastern equatorial Pacific during the last glacial maximum $(19,000$ to 14,000 yr B.P). Geology, 11, 16-19, doi: 10. 1130/0091-7613(1983)11<16:ipitee>2.0.co;2. [Link]

Redfield, A.C., 1934: On the Proportions of Organic Derivations in Sea Water and Their Relation to the Composition of Plankton, Liverpool University. Press, 182 pp.

Reimer, P. J., M. G. L. Baillie, E. Bard, A. Bayliss, J. W. Beck, P. G. Blackwell, C. B. Ramsey, C. E. Buck, G. S. Burr, R. L. Edwards, M. Friedrich, P. M. Grootes, T. P. Guilderson, I. Hajdas, T. J. Heaton, A. G. Hogg, K. A. Hughen, K. F. Kaiser, B. Kromer, F. G. McCormac, S. W. Manning, R. W. Reimer, D. A. Richards, J. R. Southon, S. Talamo, C. S. M. Turney, J. van der Plicht, and C.E. Weyhenmeyer, 2009: IntCal09 and Marine09 radiocarbon age calibration curves, 0-50,000 years cal BP. Radiocarbon, 51, 1111-1150, doi: 10.1017/ S0033822200034202. [Link]

Sarnthein, M., K. Winn, J. C. Duplessy, and M. R. Fontugne, 1988: Global variations of surface ocean productivity in low and mid latitudes: Influence on $\mathrm{CO}_{2}$ reservoirs of the deep ocean and atmosphere during the last 21,000 years. Paleoceangraphy, 3, 361-399, doi: 10.1029/PA003i003p00361. [Link]

Schlanger, S. O., M. A. Arthur, H. C. Jenkyns, and P. A. Scholle, 1987: The Cenomanian-Turonian Oceanic Anoxic Event, I. Stratigraphy and distribution of organic carbon-rich beds and the marine $\delta^{13} \mathrm{C}$ excursion. Geol. Soc. Lond. Spec. Publ., 26, 371-399, doi: 
10.1144/GSL.SP.1987.026.01.24. [Link]

Selvaraj, K., T. Y. Lee, J. Y. T. Yang, E. A. Canuel, J. C. Huang, M. Dai, J. T. Liu, and S. J. Kao, 2015: Stable isotopic and biomarker evidence of terrigenous organic matter export to the deep sea during tropical storms. Mar. Geol., 364, 32-42, doi: 10.1016/j.margeo.2015.03.005. [Link]

Shackleton, N. J., 1987: The carbon isotope record of the Cenozoic: History of organic carbon burial and of oxygen in the ocean and atmosphere. Geol. Soc. Lond. Spec. Publ., 26, 423-434, doi: 10.1144/GSL. SP.1987.026.01.27. [Link]

Shao, L., X. J. Li, J. H. Geng, X. Pang, Y. C. Lei, P. J. Qiao, L. L. Wang, and H. B. Wang, 2007: Deep water bottom current deposition in the northern South China Sea. Sci. China Ser. D, 50, 1060-1066, doi: 10.1007/ s11430-007-0015-y. [Link]

Shaw, P. T. and S. Y. Chao, 1994: Surface circulation in the South China Sea. Deep-Sea Res. Part I-Oceanogr. Res. Pap., 41, 1663-1683, doi: 10.1016/09670637(94)90067-1. [Link]

Shintani, T., M. Yamamoto, and M. T. Chen, 2011: Paleoenvironmental changes in the northern South China Sea over the past 28,000 years: A study of TEX86-derived sea surface temperatures and terrestrial biomarkers. $J$. Asian Earth Sci., 40, 1221-1229, doi: 10.1016/j.jseaes.2010.09.013. [Link]

Stuiver, M. and P. J. Reimer, 1993: Extended ${ }^{14} \mathrm{C}$ data base and revised CALIB $3.0{ }^{14} \mathrm{C}$ age calibration program. Radiocarbon, 35, 215-230, doi: 10.1017/ S0033822200013904. [Link]

Su, J. L., 2004: Overview of the South China Sea circulation and its influence on the coastal physical oceanography outside the Pearl River Estuary. Cont. Shelf Res., 24, 1745-1760, doi: 10.1016/j.csr.2004.06.005. [Link]

Sun, X. J. and X. Li, 1999: A pollen record of the last 37 ka in deep sea core 17940 from the northern slope of the South China Sea. Mar. Geol., 156, 227-244, doi: 10.1016/S0025-3227(98)00181-9. [Link]

Tamburini, F., T. Adatte, K. Föllmi, S. M. Bernasconi, and P. Steinmann, 2003: Investigating the history of East Asian monsoon and climate during the last glacialinterglacial period (0-140 000 years): Mineralogy and geochemistry of ODP Sites 1143 and 1144, South China Sea. Mar. Geol., 201, 147-168, doi: 10.1016/S00253227(03)00214-7. [Link]

Volvoikar, S. P., G. N. Nayak, A. Mazumdar, and A. Peketi, 2014: Reconstruction of depositional environment of a tropical estuary and response of $\delta^{13} \mathrm{C}_{\text {org }}$ and TOC/TN signatures to changing environmental conditions. Estuar. Coast. Shelf Sci., 139, 137-147, doi: 10.1016/j. ecss.2014.01.001. [Link]

Wan, S. M., A. C. Li, P. D. Clift, and J. B. W. Stuut, 2007: Development of the East Asian monsoon: Mineralogi- cal and sedimentologic records in the northern South China Sea since 20 Ma. Palaeogeogr. Palaeoclimatol. Palaeoecol., 254, 561-582, doi: 10.1016/j.palaeo.2007.07.009. [Link]

Wan, S. M., A. C. Li, K. H. Xu, and X. M. Yin, 2008: Characteristics of clay minerals in the northern South China Sea and its implications for evolution of East Asian Monsoon since Miocene. J. China Univ. Geosci., 19, 23-37, doi: 10.1016/S1002-0705(08)60021-7. [Link]

Wan, S. M., A. C. Li, P. D. Clift, S. G. Wu, K. H. Xu, and T. G. Li, 2010: Increased contribution of terrigenous supply from Taiwan to the northern South China Sea since 3 Ma. Mar. Geol., 278, 115-121, doi: 10.1016/j. margeo.2010.09.008. [Link]

Wang, B., S. C. Clemens, and P. Liu, 2003: Contrasting the Indian and East Asian monsoons: Implications on geologic timescales. Mar. Geol., 201, 5-21, doi: 10.1016/ S0025-3227(03)00196-8. [Link]

Wang, L. and P. Wang, 1990: Late Quaternary paleoceanography of the South China Sea: Glacial-interglacial contrasts in an enclosed basin. Paleoceanography, 5, 77-90, doi: 10.1029/PA005i001p00077. [Link]

Wang, L., M. Sarnthein, H. Erlenkeuser, J. Grimalt, P. Grootes, S. Heilig, E. Ivanova, M. Kienast, C. Pelejero, and U. Pflaumann, 1999: East Asian monsoon climate during the Late Pleistocene: High-resolution sediment records from the South China Sea. Mar. Geol., 156, 245-284, doi: 10.1016/S0025-3227(98)00182-0. [Link]

Wang, P., 1999: Response of Western Pacific marginal seas to glacial cycles: Paleoceanographic and sedimentological features. Mar. Geol., 156, 5-39, doi: 10.1016/ S0025-3227(98)00172-8. [Link]

Wang, P. and Q. Li, 2009: The South China Sea: Paleoceanography and Sedimentology, Springer Netherlands, 506 pp, doi: 10.1007/978-1-4020-9745-4. [Link]

Wang, P. and X. Sun, 1994: Last glacial maximum in China: Comparison between land and sea. Catena, 23, 341353, doi: 10.1016/0341-8162(94)90077-9. [Link]

Wang, Y. J., H. Cheng, R. L. Edwards, Z. S. An, J. Y. Wu, C.-C. Shen, and J. A. Dorale, 2002: A high-resolution absolute-dated late Pleistocene Monsoon record from Hulu Cave, China. Science, 294, 2345-2348, doi: 10.1126/science.1064618. [Link]

Wehausen, R. and H. J. Brumsack, 2002: Astronomical forcing of the East Asian monsoon mirrored by the composition of Pliocene South China Sea sediments. Earth Planet. Sci. Lett., 201, 621-636, doi: 10.1016/ S0012-821X(02)00746-X. [Link]

Wei, G. J., X. H. Li, Y. Liu, L. Shao, and X. R. Liang, 2006: Geochemical record of chemical weathering and monsoon climate change since the early Miocene in the South China Sea. Paleoceanography, 21, 271-292, doi: 10.1029/2006PA001300. [Link] 
Wilson, G. P., A. L. Lamb, M. J. Leng, S. Gonzalez, and D. Huddart, 2005: Variability of organic $\delta^{13} \mathrm{C}$ and $\mathrm{C} / \mathrm{N}$ in the Mersey Estuary, U.K. and its implications for sealevel reconstruction studies. Estuar. Coast. Shelf Sci., 64, 685-698, doi: 10.1016/j.ecss.2005.04.003. [Link]

Yang, C. P., F. Liu, X. H. Chang, Z. W. Liao, J. F. Hu, S. Li, X. J. Li, and Y.J. Yao, 2015: The n-alkane records from sediments in the base of slope (near abyssal plain) of the north-eastern South China Sea (SCS) over the last 30ka: Implications for paleo-vegetation. Quat. Sci., 35, 1-9, doi: 10.11928/j.issn.1001-7410.2015.04.10. [Link]

Yang, S. Y., W. W. S. Yim, M. Tang, and G. Q. Huang, 2008: Burial of organic carbon and carbonate on inner shelf of the northern South China Sea during the postglacial period. Frontiers of Earth Science in China, 2, 427-433, doi: 10.1007/s11707-008-0058-1. [Link]

Yang, S. Y., M. Tang, W. W. S. Yim, Y. Q. Zong, G. Q. Huang, A. D. Switzer, and Y. Saito, 2011a: Burial of organic carbon in Holocene sediments of the Zhujiang (Pearl River) and Changjiang (Yangtze River) estuaries. Mar. Chem., 123, 1-10, doi: 10.1016/j. marchem.2010.07.001. [Link]

Yang, T. N., T.-Q. Lee, P. A. Meyers, S.-R. Song, S.-J. Kao, L. Löwemark, R.-F. Chen, H.-F. Chen, K.-Y. Wei, C.W. Fan, L.-J. Shiau, H.-W. Chiang, Y.-G. Chen, and M.-T. Chen, 2011b: Variations in monsoonal rainfall over the last $21 \mathrm{kyr}$ inferred from sedimentary organic matter in Tung-Yuan Pond, southern Taiwan. Quat. Sci. Rev., 30, 3413-3422, doi: 10.1016/j.quas- cirev.2011.08.017. [Link]

Yu, F. L., Y. Q. Zong, J. M. Lloyd, G. Q. Huang, M. J. Leng, C. Kendrick, A. L. Lamb, and W. W. S. Yim, 2010: Bulk organic $\delta^{13} \mathrm{C}$ and $\mathrm{C} / \mathrm{N}$ as indicators for sediment sources in the Pearl River delta and estuary, southern China. Estuar. Coast. Shelf Sci., 87, 618-630, doi: 10.1016/j.ecss.2010.02.018. [Link]

Yuan, D. X, H. Cheng, R. L. Edwards, C. A. Dykoski, M. J. Kelly, M. Zhang, J. Qing, Y. Lin, Y. Wang, J. Wu, J. A. Dorale, Z. An, and Y. Cai, 2004: Timing, duration, and transitions of the last interglacial Asian monsoon. Science, 304, 575-578, doi: 10.1126/science.1091220. [Link]

Zhang, Y. L., K. Kaiser, L. Li, D. N. Zhang, Y. Ran, and R. Benner, 2014: Sources, distributions, and early diagenesis of sedimentary organic matter in the Pearl River region of the South China Sea. Mar. Chem., 158, 3948, doi: 10.1016/j.marchem.2013.11.003. [Link]

Zhao, Q. H., Z. M. Jian, J. L. Wang, X. R. Cheng, B. Q. Huang, J. Xu, Z. Zhen, D.Y. Fang, and P. X. Wang, 2001: Neogene oxygen isotopic stratigraphy, ODP Site 1148, northern South China Sea. Sci. China Ser. D, 44, 934-942, doi: 10.1007/BF02907086. [Link]

Zhou, B., H. B. Zheng, W. G. Yang, D. Taylor, Y. H. Lu, G. J. Wei, L. Li, and H. Wang, 2012: Climate and vegetation variations since the LGM recorded by biomarkers from a sediment core in the northern South China Sea. J. Quat. Sci., 27, 948-955, doi: 10.1002/jqs.2588. [Link] 